Historic, Archive Document

Do not assume content reflects current scientific knowledge, policies, or practices. 



\section{Retail Price List}

The following listed stock is all first class of the grade named. In case of your ordering any item in a grade we are sold on, we reserve the right to give you the next higher or lower grade. In case we are entirely sold on any item you may order, we would be glad to select some other variety of equal merit, color and season. Our judgment of what is best is at your command.

Let us book your order and we will hold until you come for it, or until time to ship.

Orders desired shipped will be packed, F. O. B. our station.

Where it is possible, it will pay you to drive to the nursery. You can drive 40 or 50 miles, get your trees, get back home and plant all or part of it the same day.

We have a commodious packing house, where stock is heeled in and properly cared for, and especially for spring is this an advantage, as we can hold stock back, so that stock may be safely handled and planted later in the season.

The percent of new trees planted each year is far below the percent of trees that are dying each year.

With the advent of modern up to date machinery for the farm, with every modern device for convenience in the home, and which includes modern up to date furniture in the home, good roads, and the luxury of travel-the automobile, people are awakening to the fact that "Its not a home until its planted."

Anticipating the needs and the demands along this line we have an unusually large and complete line of hardy Shrubbery, Roses, Hedge Plants, Climbing Plants, Shade Trees, a full line of Fruit Trees, Hardy Perennial plants for the "Flower Garden," bulbs, etc.

Last but not least we have a fine large supply in all the standard varieties in Evergreens. You should see them to appreciate them.

We have been in the business for forty-five years. Our customers are our best advertisers. We solicit your business.

NOTE-If in need of stock in larger quantities than are named in list, write for prices and will make you special quotations.

NOTE-We will allow 5 at 10 rate and 50 at 100 rate.

NOTE-In growing large quantities of stock there is sometimes stock in off grades, either smaller or larger than herein quoted.

If interested in such grades, ask for prices.

TERMS-Cash, or if sent by express, C. O. D. on delivery.

\section{The Laketon Nurseries \\ Laketon, Indiana}




\section{WHY NOT BUY MORE FRUIT TREES?}

How many dollars a year do you spend for fruit-either fresh or in cans?

Did you ever stop to think that one-tenth that sum invested in a few trees, would give you many times the amount of fruit you buy-and keep on giving it to you, year after year?

If you have ground enough for a fair-sized garden, you have room enough for fruit. A single tree will yield from 50 to 150 quarts of fruit. We have seen 2016 -quart baskets taken from a single tree, under regular commercial culture. A good young apple tree will give from two to four barrels of fruit.

Fruit trees require so little care, as compared to vegetables, that your whole home orchard will not take many hours work during the entire year.

You can grow as fine peaches and apples as sold anywhere if you plant the right kind of trees.

\section{APPLES}

No. 1 grade, 11-16 and up

Med. grade, 9-16 and up

Each

$\$ 0.75 \$ 6.50$

$65 \quad 5.50$

\section{Summer Varieties}

YEIIOW TRANSPARENT-Fruit a clear yellowish-white. Begins to ripen in July. Especially hardy.

EARTY HARVEST-Much prized by the housewife. The Early Harvest has been in cultivation for more than one hundred years and this is a proof of its excellence. It is a very early variety, ripens in July and August. It is desirable for the home orchard because of its earliness and its excellence for dessert and culinary purposes.

RED ASTRACHAN-Earliest and best red apple. Good size, dark red. Vigorous, hardy and productive.

DUCFESS OF OIDFNBURG-Medium: pale yellow, streaked red, bears young and is a good cropper; useful for fall purposes; fine for market with a great demand.

WIAITFY-Large: brilliant red; rich sub-acid flavor; excellent quality; good keeper; highly recommended; keeps well in storage.

MAIDEN'S BIUSH-Beautiful yellow apple with red cheek. One of the finest quality apples grown for eating or cooking.

\section{Winter Varieties}

BAIDWIN-This is the leading commercial variety in the American markets. It is to apples what Elberta is to peaches and Montmorency is to cherries. One of the best storage apples for export trade. Thousands of barrels of this fruit are exported to England annually. Baldwin is planted extensively and succeeds wonderfully well in all states east of the Mississippi. Fruit large, bright red, crisp, rich.

GANO- An improved Ben Davis, adding to the good qualities of that variety a much handsomer fruit of deep, dark red, that brings a ready sale in market. Dec.-March.

KING (King of Tompkins Co.) When you see in the market apples of extraordinary size, beautiful red in color, speci m e n s that attract the attention of eve r y b d y who passes by, you may know that these are King apples. Vigorous grower, $g$ ood bearer.

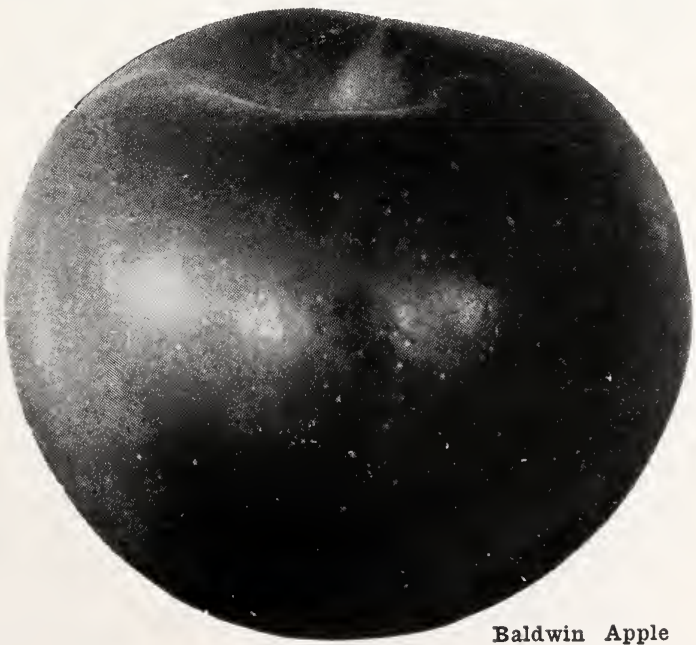




\section{APPLES-Continued}

GRIMES GOIDEN-Medium to large size; skin golden yellow, sprinkled with gray dots, flesh crisp, tender, juicy, sprightly, very good to best. Tree is very hardy and productive, and one of the best fillers, as it comes into bearing very early. Grimes' Golden is one of our few best sorts. Dec.-Apr.

JONATFAN-A beautiful red apple, highly flavored and of excellent quality, being tender, juicy, spicy, and rich-a splendid family sort and highly profitable for market. Tree long lived, productive, and an early bearer. Will keep well without special care and also stand much handling. Nov.-Jan.

NORTHER.N SPY - A hardy, large, red winter apple. Flesh juicy, rich, crisp, tender, aromatic, of good flavor. Tree very healthy, strong grower, rugged. Blossoms very late, escaping frosts. Its large size, handsome appearance and super-fine quality give it first rank for fancy trade. Dec.-Mar.

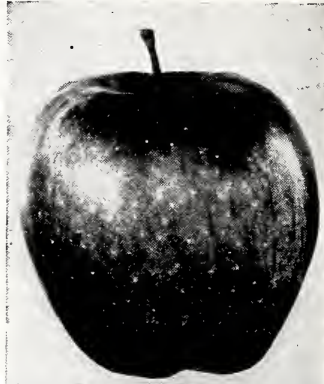

Delicious Apple

ROME BEAUTY-Large round; mottled and striped in different shades of red; flavor and quality way above the average; appearance and size are its valuable points; always sells and always brings good prices. With an established reputation due to real merit. Good grower; blooms late; bears heavily every year; is adapted to a wide range of soils, elevations and conditions. In Ohio, Pennsylvania, New York, West Virginia and Maryland will make more money than some of the sorts which are not a large part of the total number of trees in commercial orchards. Reliability, due to being frost-proof, strong-growing and sure bearing, make it a favorite with the grower.

R. I. GREENING-Large; flesh yellowish, firm, fine grained, crisp. Fine cooking. Tree large and vigorous.

STAYMAN'S WINESAP-Dark rich red striped with crimson. Flesh tinged with yellow; firm, crisp, fine-grained, very juicy, sub-acid flavor. A good one.

FAMEUSE (Snow Apple)-Medium size; deep crimson; flesh snowy white, melting and delicious, one of the finest dessert fruits. Oct.-Dec.

TAIMAN SWEET-The leading sweet apple for winter use. Pale, creamy yellow; it has a fine sweet flavor that makes it popular. Strong, large tree, bears at about 8 years. Heavy yielder; everyone likes it. Large trees, each $45 \mathrm{c} ; 10$ for $\$ 4.00$. Medium trees, $35 \mathrm{c} ; 10$ for $\$ 3.00$.

WINTER BANANA-Fruit large, perfect in form; golden yellow, and beautifully shaded and marbled with bright, crimson red; flesh lemonyellow, fine grained, sub-acid, rich, aromatic flavor and of the highest quality. A good keeper. Tree remarkably strong grower, and on account of its great hardiness, will thrive in any climate. Its early

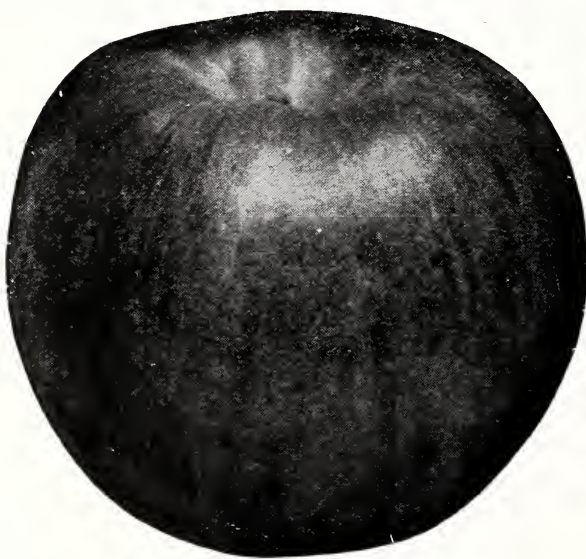
bearing is something simply wonderful, generally producing a fine crop the second year. A valuable market variety. Very popular especially in New York and Pennsylvania. Nov.-Jan.

YORK IMPERIAL- An important commercial apple. Can be kept till new crop comes. Medium sized, round, irregular; greenish-yellow overlaid with bright red stripes; flesh tender, firm, crisp, juicy, extra good flavor. Tree is a vigorous grower.

DEIICIOUS-No new variety has ever so quickly gained popularity. Fruit large, dark red, flesh fine grained crisp, Rome Beauty of highest quality. 


\section{CRAB APPLES}

FYSLOP-Deep crimson fruit with a sub-acid; pleasant flavor ;very desirable and well known.

WHITNEY-The tree is a hardy, thrifty, upright grower, and comes into bearing when young; it is a very productive variety. The flesh is yellowish, crisp, juicy and splendid for eating and cider. August and September.

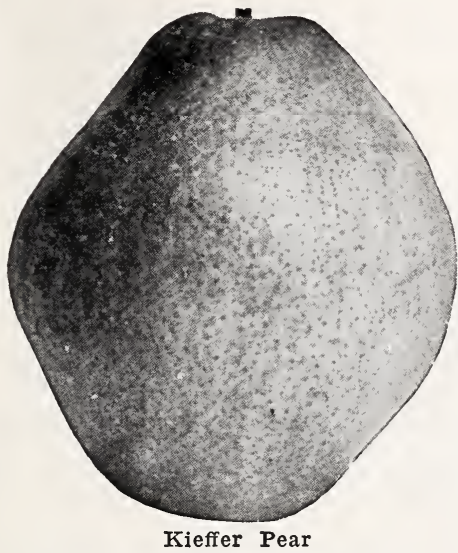

\section{PEARS}

The Pear is closely related to the apple and like the apple thrives on many soils. It is noted for its deli. cate, mild, sweet and delicious flavor, and the melting, buttery, juicy texture of the flesh, surpassing the apple in these respects.

No. 1 grade, 4 to $6 \mathrm{ft} .11-16 \mathrm{up}$, each, $\$ 1.00$, Per $10, \$ 9.00$.

Med. Grade, 4 to 5 ft., 5-8, up, each $85 \mathrm{c}$; per $10, \$ 7.50$.

BARTIFTT-Summer. A great favorite in all orchards and in all markets because of delicious flavor and fine quality. Large, coloring to waxen yellow with red blush; juicy, melting, highly flavored.

FIFMISH BFAUTY-Large size greenish yellow and brown; rich and juicy. An old and highly esteemed variety; a strong grower. and a great bearer; hardy and desirable. Fruit almost covered with light russet, becoming reddishbrown when ripe. Large, beautiful, melting, sweet and rich.

DUCHrss-A large pear, late, good quality; bears young. A fine eating pear right from the tree.

SECKEI-A beautiful and delicious little pear that is the standard of excellence in its class. One of the richest and highest flavored pears known, always in demand for desserts and luncheons and better known than any pear of its class. The tree makes a somewhat slow but stout and erect growth. Owing to its extreme hardiness it can be planted in cold climates with the assurance of best results. Sept. and Oct.

KIFFFER-This is the most popular pear grown for commercial use. Good size, rich color; tree vigorous and bears well. The blight does not hurt the Kieffer. Fruit should be picked at maturity and ripened indoors. Season Oct. to Nov.

CIAPP'S FAVORITE-Large; pale lemon yellow with red cheek: flesh of fine texture, melting buttery, juicy, with a rich vinous flavor; good for market and kitchen. August.

WIIDER-One of the very earliest pears, of excellent quality. Of medium to large size, irregular, bellshaped; pale yellow with shadings of russet-red. Early August.

\section{DWARF PEAR}

No. 1 Grade, 3 to $4 \mathrm{ft}$, 5-8 up, each $90 \mathrm{c} ;$ Per $10, \$ 7.50$.

Med. Grade, $2 \frac{1}{2}$ to 3 ft., $1-2$ up, each, $80 \mathrm{c}$; Per $10, \$ 6.50$.

VARIFTIFS - Duchess, Bartlett, Flemish, Clapps Favorite.

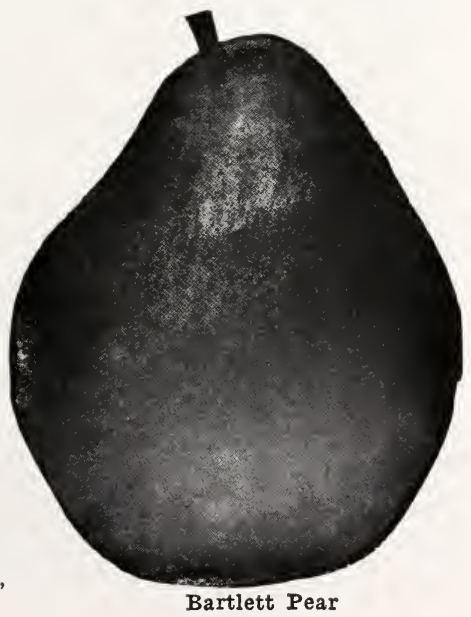




\section{CHERRIES}

While the cherry tree is of rather slow growth it is so sturdy and hearty and bears for so many years a large, bountiful crop under the most adverse conditions, that a few of them are the most valuable tree that a home man can plant.

\section{SOUR CHERRIES}

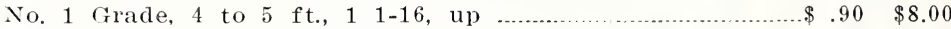

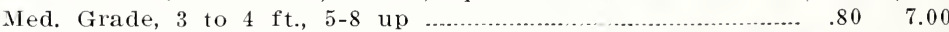

EARIY RICHMOND-Best early cherry, much like Montmorency, except perhaps a little smaller and a few days earlier; bear young and very abundantly; best home canner and pie cherry that grows. Sells well on all markets.

DYEHOUSE-Bright, red, prolific bearer. The fruit is mildy sub-acid, excellent variety for canning, good shipper. Free and vigorous. Last of May.

LARGE MONTMORENCY - We have a fine lot of Cherry trees to offer in two grades. All one year. One year trees are the very best trees to be had, and of course, the very best to set for any and every purpose. There is more money in Montmorency Cherries than any tree fruit that can be planted. There are only two or three restricted areas in the whole United States, where Montmorency Cherries do well, and the best district is the North Central states. The market is

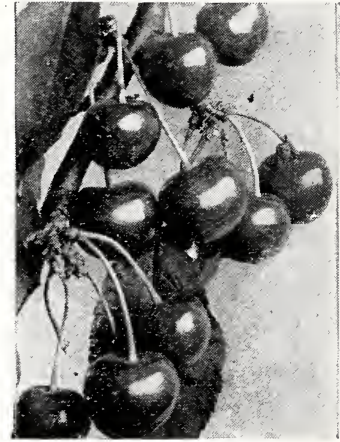

Eariy Richmond unlimited and the supply is short, with the demand for canned cher. ries on the increase.

ENGIISH MOREIIO-Without doubt one of the most valuable of this class. Easily grown, generally producing a heavy crop. Fruit dark red, quality good with a rich, acid flavor; late. Tree very hardy, for extremely cold latitudes. August.

\section{SWEET CHERRIES}

Each Per 10 $\$ 1.00 \quad \$ 9.00$ Med. Grade, 4 to $5 \mathrm{ft} ., 5-8$, up ......................................... $.90 \quad 8.00$ WINDSOR-Of Canadian origin, noted for its hardiness of both tree and bud, and its abundant bearing. Cherry is large, dull red, always a money maker. Best quality.

GOV. WOOD-A large, light yellowish cherry, excellent flavor. Ripens in June and generally liked.

ELACK TARTARIAN-A favorite everywhere; large, purplish black, firm flesh, fine flavor.

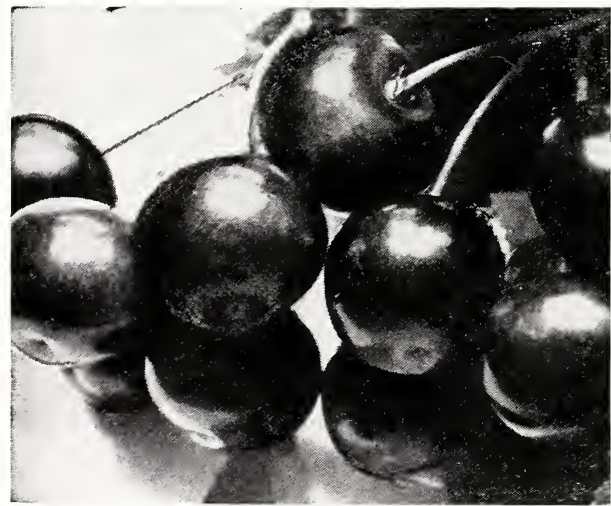

Governor Wood Cherries
NAPOLEON- Tree medium size, fruit borne generally in twos, very large. Excellent bearer.

EING-Very large, dark red; fine quality; trees are hardy and prolific.

YEIIOW SPANI买 -

L a $\mathrm{rg}$ e, handsome, sweet cherry with light red cheek, firm and delicious. Tree vigorous in growth and productive. Late June.

IAIMERT-Fine sweet variety, one of the largest of all cherries, dark purple red, turning almost jet black when ripe Flesh firm. rich, juicv. enormous bearer. Late July. 


\section{PLUMS}

The plum, like a pear, succeeds best in a rather heavy soil with some clay and being generally free from disease is profitable. They should be gathered a few days ahead of use that they may develop their perfect flavor. For family use they especially do well in poultry yards, or where the hogs keep the ground free from fallen fruit. The valieties should be mixed.

Each Per 10

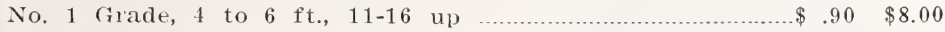

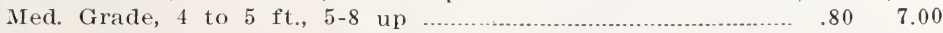

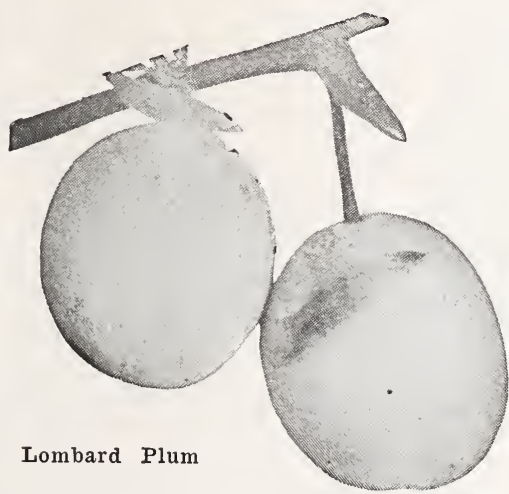
pruning. It ripens in August.

ABUNDANCE-A beautiful yellow, heavily overspread with purplecarmine; large to very large; the flesh is yellow, very juicy, sweet and quite firm; skin tough. The tree is a strong, thrifty grower, very hardy and prolific. The fruit stands shipping well to distant markets. July.

\section{GREEIN GAGE}

Rather large, oval, greenish. F l e s h juicy, rich and delicious. Middle ot August.

MOORE'S ARCTIC - Purplish black plum with a thin bloom. Fruit is small to medium; flesh juicy, sweet and fine-flavored. Tree is healthy, a regular and abundant bearer. August. YEILOW EGG-A beautiful yellow. egs-sliaped plum of the largest size; the flesh is yellow, and is somewhat coarse; always clings to the stone. This is an excellent variety for canning and always brings a good price on the market. The tree is a prolific bearer and a good grower. Late August.

IOMBARD - A favorite for canning and culinary purposes. of medium size, oval, violetred. Flesh is yellow, juicy, pleasant and good. Adheres to the stone. Good market variety. The tree is strong and productive, bearing when quite young. Ripens late in August.

BRADSHAW - Remarkably good early plum. This variety is a very large dark red. Flesh is yellow, juicy and good. A valuable market variety. Tree is an erect, vigorous grower. Middle of August.

BURBANK--Successful almost anywhere. The fruit is of very large size, the color cherry red, mottled. The flesh is yellow, sweet and firm. It is fine for keeping and shipping. The raggling that it requires sharp 


\section{PEACHES}

Every home should have a few peach trees as there is no more delicious fruit in its season, and that purchased on the market is often of an inferior quality because of the necessities of picking comparatively greell.

No. 1 Grade, 4 to $5 \mathrm{ft} .9-16$, up $\$ .50 \$ 4.00$

Med. Grade, 3 to $4 \mathrm{ft}, 7-16$, up

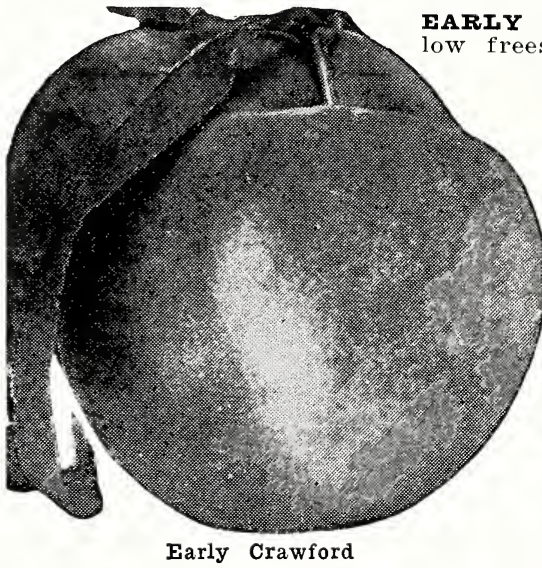

GARIY CRAWFORD-Mid-season yeltone. Better quality, hardier, better in every way than old Crawford Early. Deep yellow, bright blush; sweet, rich, fine quality. Trees hardy, healthy, vigorous, good bearer. Ripens 7 days before Elberta.

IATE CRAWTORD-A very large yellow freestone of the finest quality. Ripens early in September.

FIRERTA - The leader of all peaches. The greatest commercial variety on the market. Fifty per cent or more of all the peaches planted are Elberta. It will thrive where any peach can be grown. It is hardy and a uniform cropper. Large, yellow with red cheek; juicy. Freestone. Season medium, ripens in early August.

CHAMPION-Large and beautiful. Flavor delicious, sweet, rich, juicy: skin creamy white with red cheek. Freestone. It is very hardy and has withstood a temperature of 18 degrees below zero and produced a good crop. Season just before the Elberta. Last of July.

NFW PROLIFIC-Early, ripens before Elberta. Yellow, heavy bearer, needs thinning; of best quality. Good-sized when properly grown. No peach is better.

KAIAMAZOO-A big money-maker. Midseason. Yellow; heavy bearer.

CARIMAN-Medium to large red freestone; very fine quality and a good shipper; heavy bearer; fruit must be thinned to insure good sized peach. No other peach will equal it. Meat very juicy and tinted with red to the seed.

J. H. FATE-A newer variety, much like the Elberta but is claimed to ship well and hang on the tree for a longer season than the Elberta. Yellow freestone, good qualty.

FITZGFRADD - The Fitzgerald is of Canadian origin and it is one of the hardiest peaches both in tree and bloom. Large yellow, freestone, firm juicy.

HFATH CIING - The old standby in the cling. Large, white, very juicy and sweet. Season first to middle of September.

Add a few more peach trees to your collection. You will never be sorry when they begin to bear.

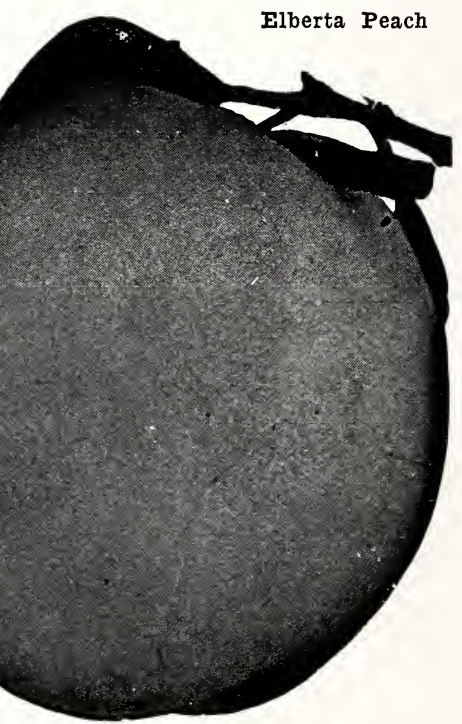




\section{QUINCE}

The Quince is always in demand, although its commercial value has changed but little for many years. Quinces are largely used in cooking, canning and preserving, as they have a delicious flavor.

No. 1 Grade, $31 / 2$ to $4 \mathrm{ft} ., 1-2$ up ...................................... $\$ .90 \quad \begin{aligned} & \$ \\ & \$ 8.50\end{aligned}$ Med. Grade, $2 \frac{1}{2}$ to $3 \mathrm{ft}$. $.80 \quad 7.50$

ORANGE-Large brilliant yellow; flesh tender, flavor good.

CHAMPION-Good bearer; very large; good keeper.

MFECH'S-Ripens earliest of all; very large.

\section{GRAPES}

Grapes are one of the most productive and hardy fruits that we have. They can be grown in small spaces and trained up the sides of buildings or along fences, occupying very little room.

2 yr. No. 1

Each Per 10

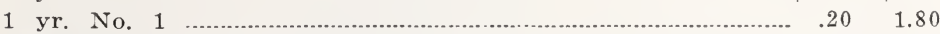

CONCORD - The fine old popular market variety and the leading commercial grape of today. A large, purplish black grape, very hardy and productive. The bunches are iarge and well filled and vines vigorous, hardy and free from disease. Does well on any soil and is the biggest money maker in grapes. Is well and favorably known whereever grapes are sold and has an established reputation on the market. Is considered the standard by which grape prices are judged. We have a large stock of Concord in all grades this year and are offering them at bargain prices. These plants were all grown and graded under our personal supervision and we guarantee them to be exactly as represented and to be of exceptional value at the price asked.

MOORE'S EARIY-Very large and round. Color black with a blue bloom. Quality very fine and sweeter than Concord. They stand handling and shipping and have an established reputation on the market. Vines hardy and productive. Ripens early.

WORDEN-Lárge, round grape, black in color. Flesh has a fine flavor unequalled by any other grape; delicious and melting; excellent for home use and a good market variety. Does not produce so heavily as the Concord so it is not planted so extensively for market. Vines are thrifty and hardy. Ripens with the Concord.

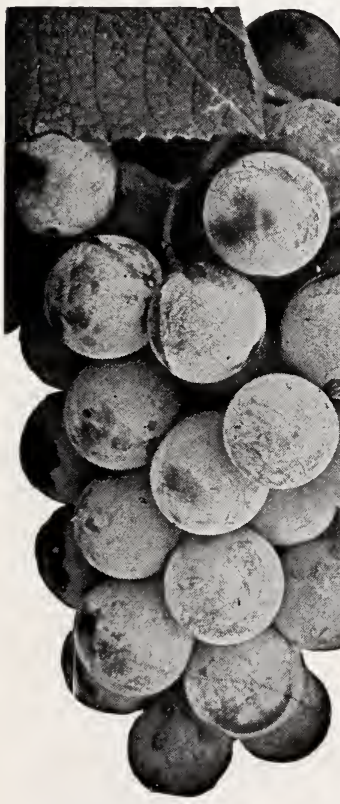

Concord Grapes
NIAGARA - The standard white grape of the country. Grape large, slightly oval in shape, pale yellow in color with a white bloom. Quality of the best. Bunches are large and compact. Vines vigorous, hardy and productive. Ripens with the Concord.

BRIGHTON-In our estimation the best all-round red grape. Bunches large, long and shouldered. Berries are medium size, skin thin, flesh very tender, sweet and best quality. Ripens early and is productive and vigorous.

AGAWAM-Deep red or maroon. The large meaty berries which are borne in extra large, looseshouldered bunches, are juicy and of a delightful aromatic flavor Ripens about with Concord or a trifle later. Strong healthy grower.

DEIAWARE-Small, red, delicious, a very popular eating grape; commands a good price on the market; hardy.

Order a few fruit trees with your shrubs. In a comparatively short time they will be furnishing the table with delicious fruit. Our stocks are complete, so send your order now. 


\section{BLACKBERRIES}

Each 7c; 10, 60c; 100, $\$ 3.50$. SNYDER-Very hardy, great producer, medium size and and one of the best known varieties of blackberries.

RATHBUR: - The largest and most productive and best flavored blackberry ever produced.

EARIY HARVEST-Anyone with a good local market will find this variety very profitable as it bears early and over a long season. Fruit medium sized, good quality, a very sweet delicious flavor. LUCRETIA-Is an old standard variety, is well liked and popular and profitable. Berries large, long, sweet, juicy and good quality. Vines very productive, hardy, thrifty, an

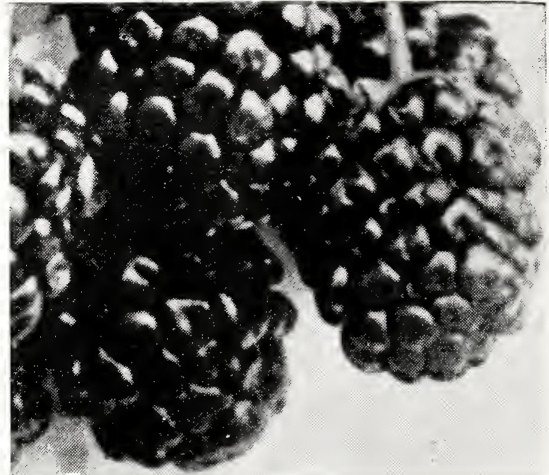

Lucretia Blackberries

\section{RASPBERRIES}

Each $7 \mathrm{c}$; per $10,60 \mathrm{c}$; per $100, \$ 3.00$.

CUMBERLAND-Largest of all black caps; firm, a good shipper, one of the most profitable market berry. Very choice black cap.

KANSAS-Strong, vigorous grower. Will grow with less care than any other of the "tip" varieties.

GREGG-Large, showy, black, firm, and will ship well. Hardy and vigorous grower. Ripens about mid-season.

CUTHBERT-Large, dark crimson, sweet, rich, highly flavored.

COLUMPIAN-Very large, deep purplish-red; sweet and highly flavored; for kitchen and market. Bush vigorous and large grower. Each $7 \mathrm{c}$; per $10,60 \mathrm{c}$; per $100, \$ 4.00$.

\section{STRA WBERRIES}

SENATOR DUNLAP-Large, handsome, rich, fine-flavored, dark ${ }^{\circ}$ red berries, which are uniform in size and shape and very attractive. 25c per $10 ; \$ 1.00$ per $100 ; \$ 8.00$ per 1000 .

GIBSON-Dark red, excellent quality and flavor, firm, stands shipping as well as any variety known. $25 \mathrm{c}$ per $10 ; \$ 1.00$ per $100 ; \$ 8.00$ per 1000 .

HAVERLAND-Tonderful productiveness, excellent flavor, one of the best. $25 \mathrm{c}$ per $10 ; \$ 1.00$ per $100 ; \$ 8.00$ per 1000 .

LLOYDS FAVORITE-25c per $10 ; \$ 1.00$ per $100 ; \$ 8.00$ per 1000 .

RR. BURRILI-Strong, vigorous plants, heavy producer of high class berries. $25 \mathrm{c}$ per $10 ; \$ 1.00$ per $100 ; \$ 8.00$ per 1000 .

SUPERB-Very large, dark red and glossy; fine quality. Begins to

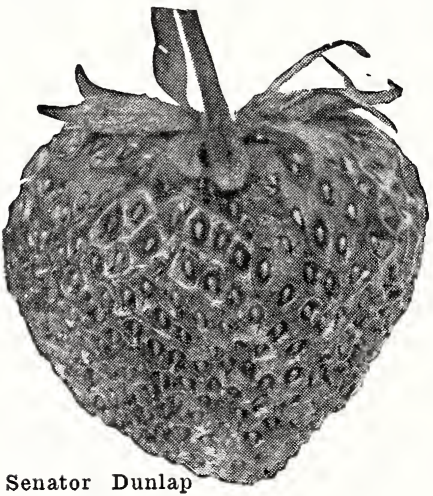
bear in June. Immense crops. $50 \mathrm{c}$ per $10 ; \$ 2.00$ per $100 ; \$ 18.00$ per 1000 .

MASTODON-Large size and great productiveness that makes Mastodon stand out away ahead of other everbearers. $75 \mathrm{c}$ per $10 ; \$ 3.00$ per 100 ; $\$ 25.00$ per 1000 .

\section{CURRANTS}

Cherry, Fays, white Grape, wilder. Fach 25c; per 10, $\$ 2.00$.

\section{GOOSEBERRIES}

Downing, Houghton, Pear. Each $30 \mathrm{c}$; per $10, \$ 2.25$.

\section{ASPARAGUS}

2 yr. roots, each 5c; per 10, 40c; per $100, \$ 2.50$.

\section{RHUBARB OR PIE PIANT}

Divided roots, each $15 \mathrm{c}$; per $10, \$ 1.25$ per $100, \$ 8.00$. 


\section{MAKING THE HOME BEAUTIFUL}

More attractive homes! Homes larger, better built, more convenient, more attractive. Not only for more heat, more light, more comfort, but also more beauty.

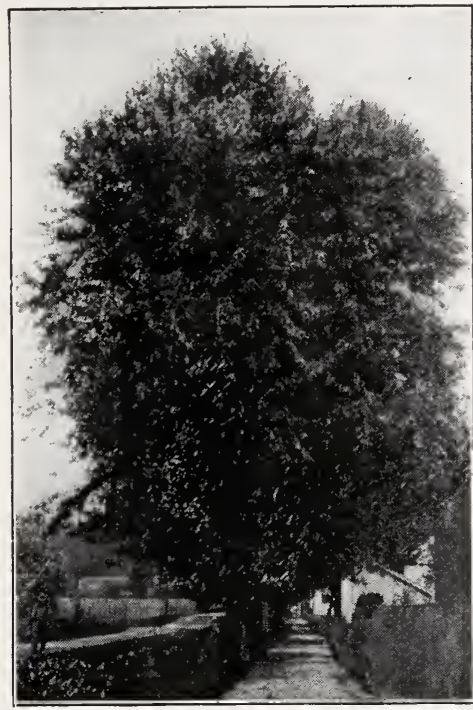

Soft Maple

When God made this country it was a place of trees, shrubs and flowers. Today men are beginning to realize that God's way is the best and everywhere men and women are striving to retain as they can. Parks and reserves for much of that former beauty as everybody, playgrounds for children, green lawns and shrubs and trees and flowers. Civic centers for making better eitizens.

Your own home, too, may be likewise a center of beauty at how small a cost many people do not realize. A little loving care is the largest item. Making the desert blossom like the rose is figurative, but making the home grounds more attractive is one step in the process.

\section{SHADE TREES}

\section{MAPIE}

A very handsome tree attaining large proportions, its spreading branches form a dense, round head and is especially desirable for street or lawn planting.

SOFT MAPIE-A rapid growing tree of large size, irregular rounded form; foliage bright green; for streets and parks; attains about the same height as Norway.

6-7 ft. 1 to $1 \frac{1 / 4}{\mathrm{in}}$. caliper, each $\$ 1.25 ; 7$ to $9 \mathrm{ft}, 1_{1 / 4}$ to $1 \frac{1}{2}$ in. caliper, each, $\$ 1.50 ; 9$ to $10 \mathrm{ft}$. $1 \frac{1 / 2}{2}$ to 2 in. caliper, each $\$ 2.00 ; 10$ to $12 \mathrm{ft.,} 2$ to $2 \frac{1}{2}$ in. caliper, each $\$ 2.75$; larger sizes, from 3 to 5 in. write for prices.

HARD MAPIE-A well known native tree, valuable for the production of sugar and wood; very desirable as an urnamental shade tree.

$1 \frac{1 / 2}{2}$ to 2 in. 2 to $21 / 2$ in. $2 \frac{1}{2}$ to 3 in. 3 to $31 / 2$ in.

NORWAY MAPLE - A very handsome tree attaining large proportions, its $\mathrm{s}$ preadi $\mathrm{n} g$ branches form a dense, round head and is especially desirable for street or lawn planting. Has five lobe leaves, bright green, lighter underneath and smooth on both surfaces, fading to yellow and gold.

7 to $8 \mathrm{ft}$

$\$ 3.00$

$1 \frac{1 / 4}{10} 1 \frac{1 / 2}{}$ in.

$1 \frac{1}{2}$ to 2 in.

4.75

2 to $2 \frac{1}{2}$ in.

5.75 prices.

SCHWEIDIER - One of the most beautiful of the shade trees. In early spring the young leaves are bright red, changing to purplish green. Tree has a round, compact head.

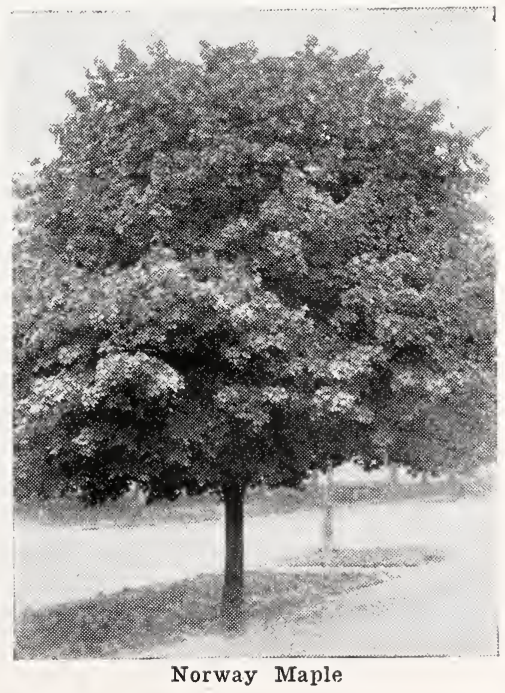




\section{SHADE TREES-Continued}

$4-5$ ft., $3-4$ to 1 in. caliper

$\$ 2.75$

5-6 ft., 1 to $1 \frac{1}{4}$ in. caliper

3.50

6-7 ft., $1 \frac{1}{4}$ to $1 \frac{1}{2}$ in. caliper

4.75

7 to $9 \mathrm{ft}$.

5.75

ASY IEAVED (Box Elder) - A rapidly growing tree with spreading branches. Frequently planted as an ornamental, but especially popular as a wind break or for timber because very hardy, withstanding cold and drought.

6 to $7 \mathrm{ft}, 1-1 \frac{1}{4}$ in. caliper

$\$ 1.00$

7 to $8 \mathrm{ft}$., $1 \frac{1 / 4-1}{1 / 2}$ in. caliper

1.50

8 to $10 \mathrm{ft}, 1_{1 / 2}^{1 / 2} \mathrm{in}$. caliper

2.50

\section{BIRCH}

A beautiful tree with white bark and in age spreading and pendulous branches. Very effective for landscape.

WHITE BIRCF-Of wonderful grace and beauty. Tall, vigorous with slender branches: foliage colors brilliant in fall, and its bare white trunk and branches are very beautiful in winter.

4 to $5 \mathrm{ft}$.

$\$ 1.75$

5 to $6 \mathrm{ft}$

2.25

6 to $8 \mathrm{ft}$.

2.75

8 to $10 \mathrm{ft}$.

3.50

CUT IEAVED BIRCF-Trembling, vigorous and hardy. A most beautiful tree with its leaves trembling in the lightest breeze. Its bark glistening from bright foliage and sparkling in the sun.

4 to $5 \mathrm{ft}$.

5 to $6 \mathrm{ft}$.

3.50

6 to $8 \mathrm{ft}$.

8 to $10 \mathrm{ft}$.

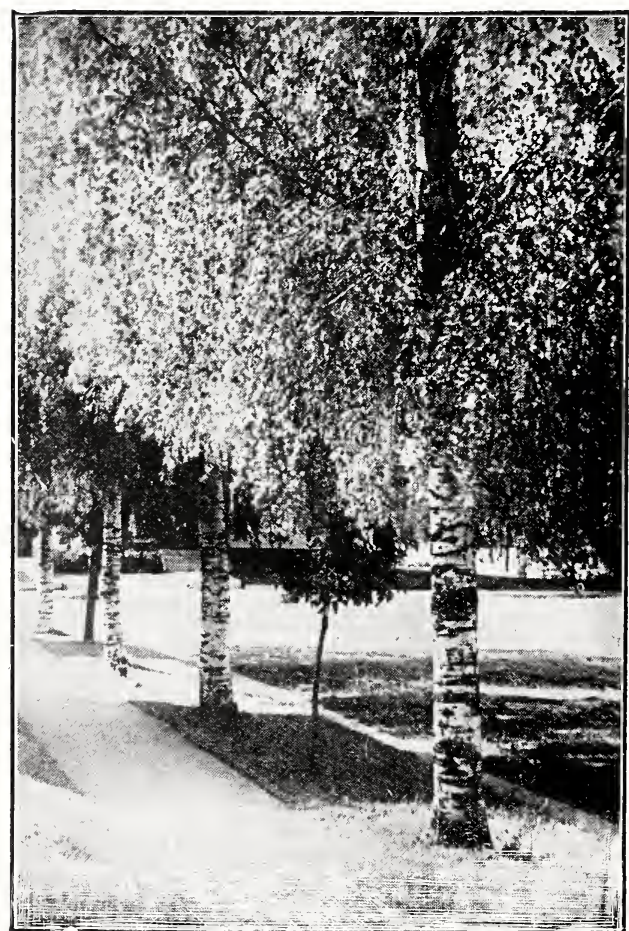

Birch Trees

\section{ELM}

MOIINE- A valuable new type, compact but fast growing habit; large dark leaves, smooth glossy bark.

4 to $5 \mathrm{ft}$.............. $\$ 1.00$

5 to 6 it. ................ 1.50

6 to $8 \mathrm{ft}$.................... 2.00

AMRRICAN - W e 11

known, graceful dependable tree.

4 to $5 \mathrm{ft}$............... $\$ 1.00$

5 to $6 \mathrm{ft}$........................ 1.50

6 to $8 \mathrm{ft.} \ldots \ldots \ldots \ldots . . . . . .2 .00$

8 to $10 \mathrm{ft} . \ldots \ldots \ldots \ldots . . .2 .75$

\section{ASH}

A well known native tree; very straight with broad, round head and dense foliage that is dark green above and light silvery beneath, fading to golden yellow. A beautiful and desirable shade tree.

GUROPEAN MOUN-

TAIN-An ornamental deciduous tree with beautiful foliage which turns orange-red in the fall. The fruits are showy and often re. main all winter, if not eaten by the birds. Not particular as to soil.

4 to $5 \mathrm{ft}$. $\$ 1.25$

5 to $6 \mathrm{ft}$

6 to $8 \mathrm{ft}$.......................... 2.00

8 to $10 \mathrm{ft}$..................... 2.75 


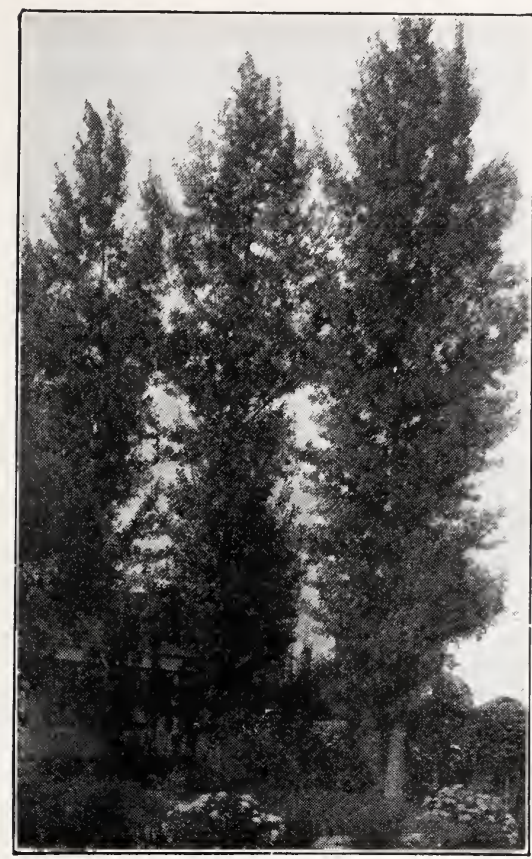

Lombardy Poplar

\section{TULIP TREE}

A tall, pyramidal trunk rises to a great height and is clothed with a splendid foliage of large, glossy leaves: large, tulip-shaped flowers are borne in the spring, greenish yellow and orange. One of the most distinguished of tall trees.

3 to $4 \mathrm{ft}$.......................... $\$ 1.00$

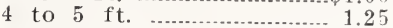

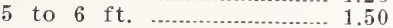

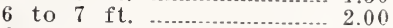

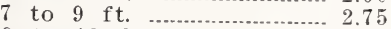

9 to $12 \mathrm{ft}$. .................................. 3.75

\section{POPLAR}

Attains a height of from one hundred to one hundred and fifty feet; well known for its erect rapid growth and tall, spiry form; indispensable tree for landscape gardening or to break the monotony of most other trees.

IOMBARDY POPLAR- A very tall and graceful tree, often attaining a height of 100 feet. It is splendid for backgrounds or borders as its tall and spiry growth makes it invaluable for landscape gardenings. A beautiful specimen tree.

6 to $8 \mathrm{f} \cdot \mathrm{t}$.

$2 \frac{1}{2}$ to 3 in.

SIMONT POPLAR A recent introduction and a very satisfactory tree Of rapid pyramidal growth, resembling Lombardy poplar, but more healthy than the latter variety. Can be used to advantage wherever a tall, pyramidal tree is desired.

5 to $6 \mathrm{ft}$.

6 to $7 \mathrm{ft}$.

$2 \frac{1}{2}$ to $23 / 1$ in.

3.50

SCARLET MAPLE-This is a very beautiful ornamental tree and is in great demand for street, lawn and park planting. A very rapid growing, hardy shade tree. Thrives equally well on well drained or low swampy, wet locations. The foliage is of an attractive, silvery color and the tree is bell shaped. Should be planted in large quantities.

4 to $5 \mathrm{ft}$.

$\$ 1.25$

5 to $6 \mathrm{ft}$.

2.00

GINNAIA-A low growing, very hardy tree. Beautifullv colored foliage in the spring a:d fall of the year. Leaves somewhat similar in shape to the Japanese Maple. Hardier than any other maple. Used very often in shrubbery planting, windbreaks and screens.

Dwarf, 3 to $4 \mathrm{ft}$.

\section{A TWO-FOLD OBJECT}

Landscape has a two-fold object-beauty and utility. The plan must provide for pleasing views, beautiful foliage and charming flowers, the whole making a harmonious picture. It must also provide for convenient walks and drives, ease of handling, and, not the least important, economy of space. 


\section{WEEPING TREES}

CATAIPA, BUNGPI-Fine for parks, lawns or cemeteries. Called by many the "Umbrella Tree." Has a dome-shaped head, large soft leaves. It is our finest Catalpa and very ornamental. Many times you will see them set on each side of a walk. 1 yr. head ...................................... $\$ 2.25$ 2 yr. head ..................................... 2.75

TEAS' WEEPING MUIBERRY Willowy drooping, or weeping branches. Very ornamental, 3 to 5 ft. at $\$ 3.50$ each; 2 for $\$ 6.00$. 1 yr. head 2 yr. head

$\$ 2.75$ 3.75

\section{WILLOW}

A medium sized tree with compact habits, leaves shiny dark green and fragrant when bruised, the odor resembling the Bay tree.

wISCONSIN WIILOW - Hardy strong, beautiful, weeping, and quick grower.

5 to $6 \mathrm{ft}$.

6 to $7 \mathrm{ft}$.

7 to $8 \mathrm{ft}$.

8 to $10 \mathrm{ft}$.

$\$ 1.00$

1.25

1.50

2.00

GOLDEN WIILOW-A strong and the most vigorous grower of all the weeping willows. Used for planting in low places or on the banks of streams, springs, lakes or ponds, making a very beautiful effect.

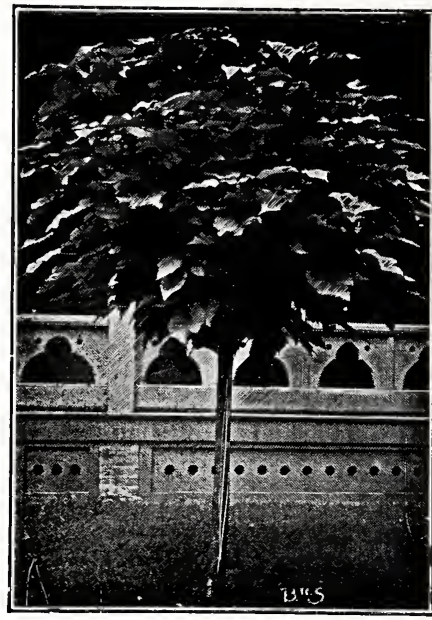

Catalpa, Bungei

5 to $6 \mathrm{ft}$.

$\$ 1.25$

6 to $8 \mathrm{ft}$.

1.50

PUSSY WII工OW-You can grow them on your own lawn. Enjoy these dainty silvery flowers every winter. A beautiful round shrub in summer. Wherever you have room for a Lilac or Snowball, you have room for a Pussy Willow. Use them for tall screens or backgrounds.

3 to $4 \mathrm{ft}$. $\$ .75$

4 to $5 \mathrm{ft}$. $\$ 1.00$

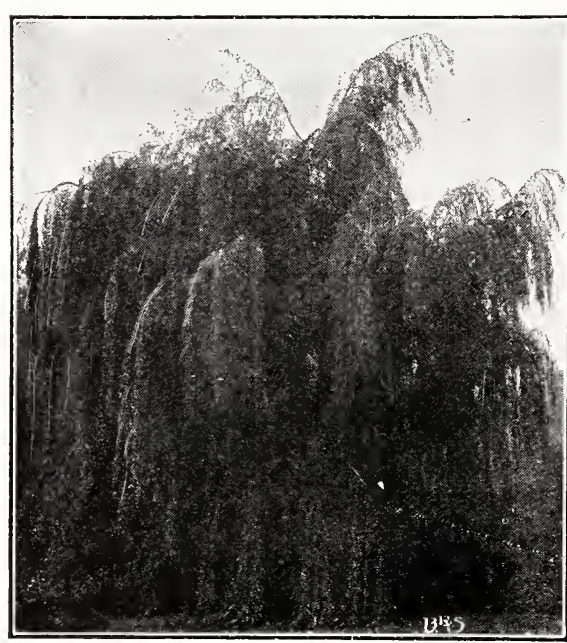

Wisconsin Willow

\section{Flowering Trees} BFCHTEI'S FIOWERING CRAB-The most beautiful of the flowering crabs. The trees rarely grow over twenty-five feet, and bloom when quite young. At a distance the fragrant, delicate pink flowers look like dainty little roses.

2 to $3 \mathrm{ft}$... $\$ 1.25$

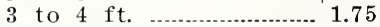

4 to $5 \mathrm{ft}, 2.25$

P A U I, S FIOWERING THORN - Flowers deep crimson scarlet, very double. This is one of the most attractive trees for specimen planting or groups, as showy in fruit as when in flower.

2 to $3 \mathrm{ft}$..................... $\$ 1.25$

3 to $4 \mathrm{ft}$............................ 1.75

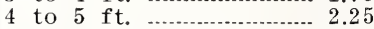

Our shrubs are large beautiful specimens and are not to be compared with mail order sizes. Fine for groups or single specimens. 


\section{SHRUBBERY}

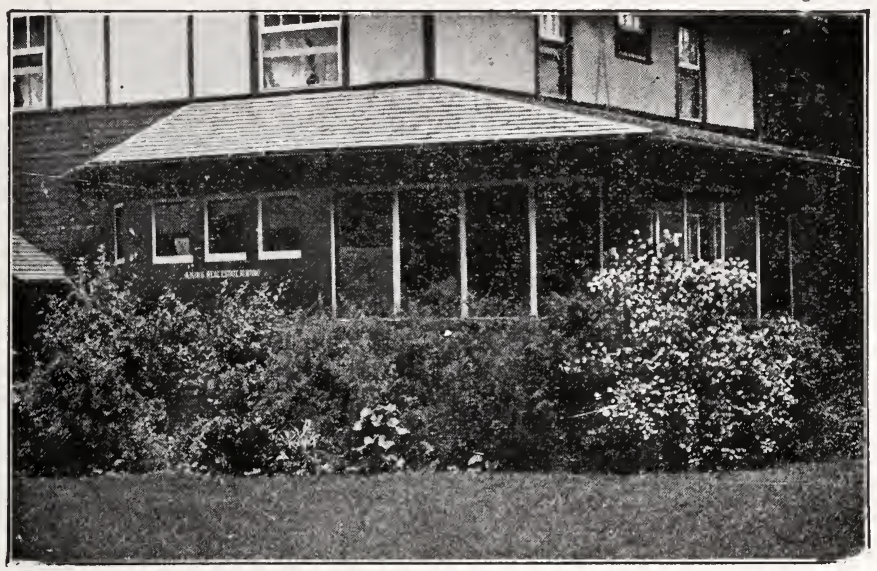

A good collection of Shrubs is not only an unfailing source of pleasure but is absolutely indispensable to the well arranged lawn. Nature plants shrubs with lavish hand along the lorders of the woodland. The effect is always restful and beautiful. The attractive home is the one neatly planted with Trees, Shrubs and flowers. Shrubs planted along the borders, massed into the corners, against the porches and sharp angles of the house will greatly enhance the artistic value of any home. Shrub plantings are the harmonizing feature which link the trees, buildings and lawn into one harmonious whole and give that finishing touch of hominess so sreatly desired.

AMORPHA, FRUITICOSA-18 to 24 in. $60 \mathrm{c} ; 2$ to $3 \mathrm{ft} .75 \mathrm{c}$.

ROSE OF SHARO:N-(Altheas). Wight to ten feet high, resembling small flowering tree; planted closely together they make a good flowering hedse. Blossoms late in the fall. A number of colors.

Red, 18 to 24 in. $40 \mathrm{c} ; 2$ to $3 \mathrm{ft} ., 50 \mathrm{c} ; 3$ to $4 \mathrm{ft} .60 \mathrm{c}$.

White, 18 to 24 in. $40 \mathrm{c} ; 2$ to $3 \mathrm{ft} .50 \mathrm{c} ; 3$ to $4 \mathrm{ft} .60 \mathrm{c}$.

Pink, 18 to 24 in. $40 \mathrm{c} ; 2$ to $3 \mathrm{ft} .50 \mathrm{c} ; 3$ to $4 \mathrm{ft} .60 \mathrm{c}$.

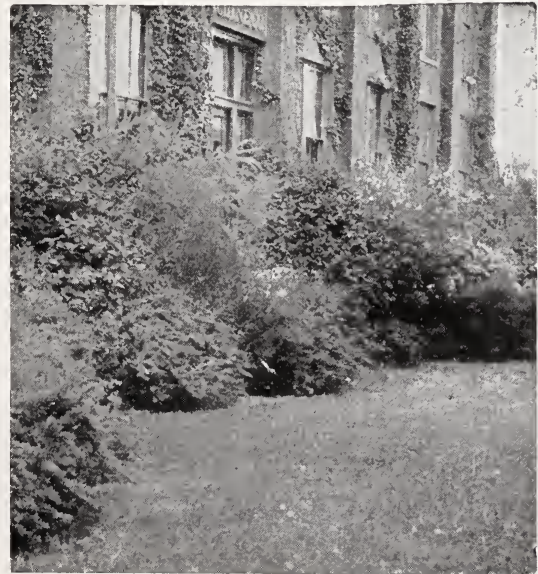

Ornamental Shrubs
Purpie, 18 to 24 in., $40 \mathrm{c} ; 2$ to $3 \mathrm{ft}$. $50 \mathrm{c} ; 3$ to $4 \mathrm{ft} .60 \mathrm{c}$.

Tree form, red, white, pink, purple, 3 to 4 ft. $\$ 1.00 ; 4$ to $5 \mathrm{ft} . \$ 1.50$.

BUTTERFIY BUSH- This shrub of comparatively recent introduction has grown into favor almost immediately. It is a semi-herbaceous plant. by which we mean in some latitudes it will die down to the ground during winter and while perfectly hardy, we recommend covering the roots with manure, leaves, or other material as winter approaches, as it will help to produce a heavy growth the next season. It is very hardy. blooms the first season, usually from June until frost. The flower head frequently being ten inches long.

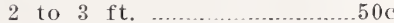

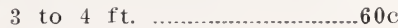




\section{SHRUBS-Continued}

CIETHRA- ( Sweet Pepper Bush) - A native shrub, to four feet, bearing profusely spikes of yellowish-white scented flowers in August.

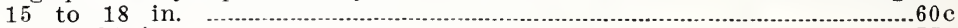
18 to 24 in. $.75 \mathrm{c}$

ARAIIA (Spinosa)-A shrub, sometimes growing to 15 feet in height. Stout prickly stems, large leaves, enormous clusters of flowers, give this species a very subtropical appearance.

3 to $4 \mathrm{ft}$.

$60 \mathrm{c}$

4 to $5 \mathrm{ft}$.

$75 \mathrm{c}$

Pentapinylla, 2 to $3 \mathrm{ft}$................................ 3 to 4 ft.

$.60 \mathrm{c}$

FIOWFRING ALMOND-This old-time favorite with its wealth of double, pink flowers, strung along the stems like so many gems, should find a place on every lawn. Their wealth of blossoms coming to delight us at a time when there are few other shrubs in bloom. Do not compare our own rooted plants with budded or grafted ones.

White, 2 to $3 \mathrm{ft}$.

$60 \mathrm{c}$

3 to $4 \mathrm{ft}$.

$75 \mathrm{c}$

Pink, 2 to $3 \mathrm{ft}$.

$.75 \mathrm{c}$

3 to 4 ft.

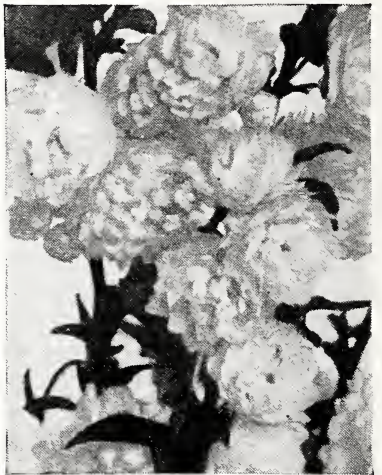

Flowering Almond

CAIYCANTHUS (Sweet Scented Shrub)-The popular, sweet-scented shrub. Blooms in June to July, has a very dark chocolate colored flower of wonderful fragrance. A branch of this shrub will scent the house or room with a wonderful, rich, spicy fragrance for days. The shrub has a beautiful waxy, dark, glossy green foliage that is sub-tropical in appearance. It is hardy.

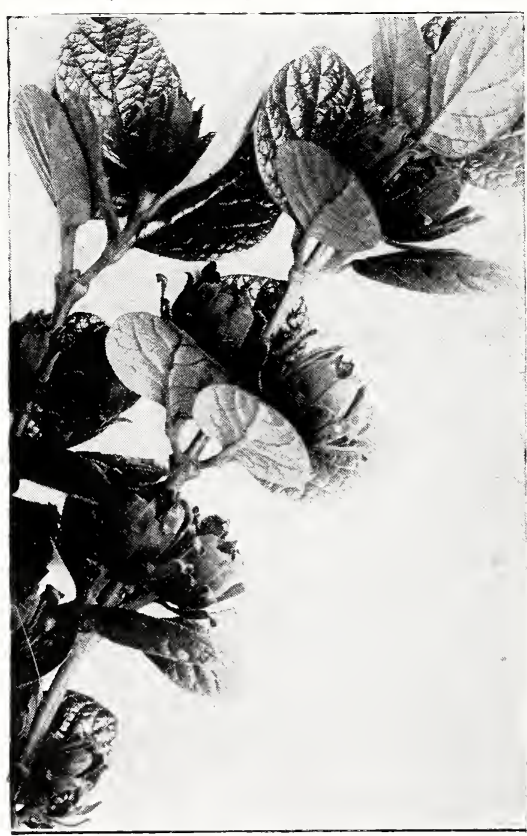

Calycanthus

12 to 18 in.

$.50 \mathrm{c}$ 18 to 24 in. .....60 CORAI BERRY-Very similar to Snowberry except that its berries are red.

2 to $3 \mathrm{ft}$. ................................. $40 \mathrm{c}$

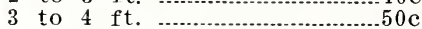
CORNUS-(Siberica). A tall shrub with bright, coral-red branches, making it especially ornamental during the winter. Has abundant small white blossoms borne in early summer and followed by white fruit. Foliage is a bright green and very attractive.

2 to $3 \mathrm{ft}$.................................. $50 \mathrm{c}$

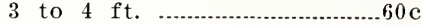

Iutea-Yellow branched variety.

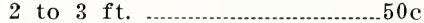

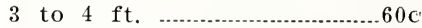
Paniculata, much branched; fruit white on red twigs.

2 to $3 \mathrm{ft}$.......................... 3 to $4 \mathrm{ft}$......................................

Elegantissima - Variegated Leaf, dwarf shrub, red bark, white and green foliage.

2 to $3 \mathrm{ft}$.

$60 \mathrm{c}$

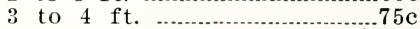

Our shrubs are large beautiful specimens and are not to be compared with mail order sizes. Fine for groups or single specimens.

Do not delay another season in planting at least some shrubs, for they add materially to the beauty and attractiveness of any home. 


\section{SHRUBS-Continued}

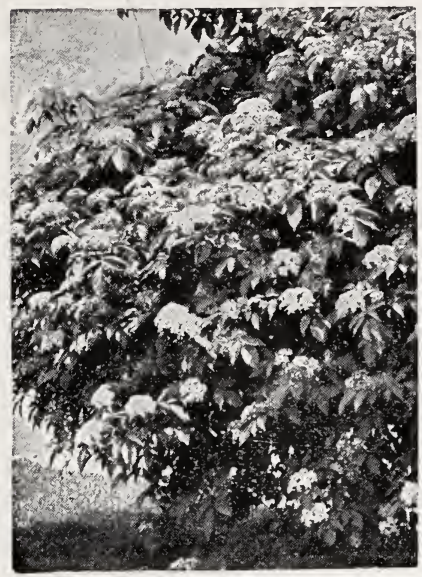

Golden Elder

COTONEASTER (Actuafolio)- Has horizontal branches with roundish deep green leaves. The bright red fruits are very attractive in September. Th:s is a noost excellent shrub in rock gardening.

18 to 24 in.

$75 \mathrm{c}$

2 to $3 \mathrm{ft}$.

$\$ 1.00$

CYDONIA (Japonica) (Japan Quince) -Common garden form, growing from 3 to 6 feet with spreading, spiny branches. The scarlet-red flowers appear before the leaves and are followed by globular fruits from one and one-half to two inches high.

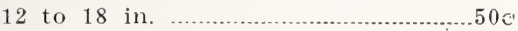

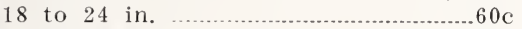
2 to $3 \mathrm{ft}$................................................ CARAGANA (Siberian Pea)- Tall shrub with fine, feathery foliage and yellow flowers in May. Fine for mixed plantings.

2 to $3 \mathrm{ft}$.

$.50 \mathrm{c}$ 3 to $4 \mathrm{ft}$.

GOIDEN IEAVED EIDER-A variety with golden yellow foliage. A valuable plant for producing contrast when planted with other shrubs. Grows to a height of about 8 feet, and is of vigorous, spreading habit. The berries, as one of the American Elder, are edible, but more red in color. Should have full sun to give best effect. Grows well on all soils and can be pruned into a neat compact little bush. One of the best golden foliaged shrubs. Blooms white in July, followed by large clusters of berries.

2 to 3 ft.

$50 \mathrm{c}$ 3 to $4 \mathrm{ft}$. $.60 \mathrm{c}$

CUT-IEAVED EIDER - Its foliage is finely split up like the fingers of the hand. Very fine and interesting; besides it bears great clusters of useful berries.

2 to $3 \mathrm{ft}$.

$50 \mathrm{c}$ 3 to $4 \mathrm{ft}$.

EXOCHORDA ( $\mathrm{P}$ e a $\mathrm{r} 1$ Bush)-A medium sized shrub with tea green foliage. Coming into flower when most shrubs are out of bloom. The white flower's appear like pearls set among the darker foliage.

18 to 24 in. ................ $60 \mathrm{c}$ 2 to $3 \mathrm{ft}$..................... $75 \mathrm{c}$

\section{DESMODIUIM (Japan} Clover) -12 to 18 in. $60 \mathrm{c}$ 18 to 24 in. ................ 75 c

IEUTZIA (Pride of Rochester-This is a choice, almost new variety that should be planted more generously. It excels in vigor, size and freedom of bloom and length of panicles. The flowers are double white, tinged on outer border with pink, blooms in June; earlier than other kinds. Fine for single planting or groupings.

2 to $3 \mathrm{ft}$. .$\check{0} 0 \mathrm{c}$

3 to $4 \mathrm{ft}$. $60 \mathrm{c}$

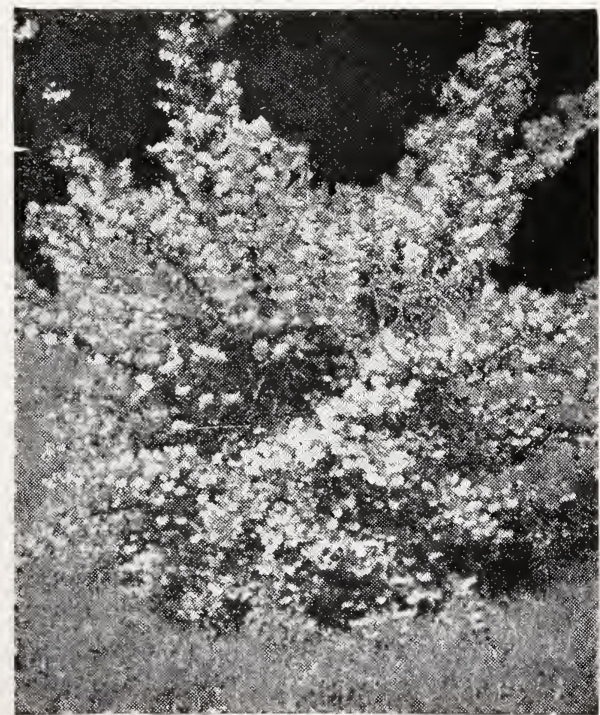

Deutzia 


\section{DEUTZIA (Continued)}

DEUTZIA CRENATA-Flowers are much like those of Pride of Rochester only are full rose pink, and are borne on long slender branches in June. Bush is real hardy and a vigorous grower; there should be more of these planted.

2 to $3 \mathrm{ft}$. 3 to $4 \mathrm{ft}$.

\section{DEUTZIA} feet in shrub to three white flowers appear in broad panicles. A very desirable shrub, more vigorous and with more showy flowers than some of the other forms. Excellent for forcing. Very hardy.

18 to 24 in.

2 to 3 ft.

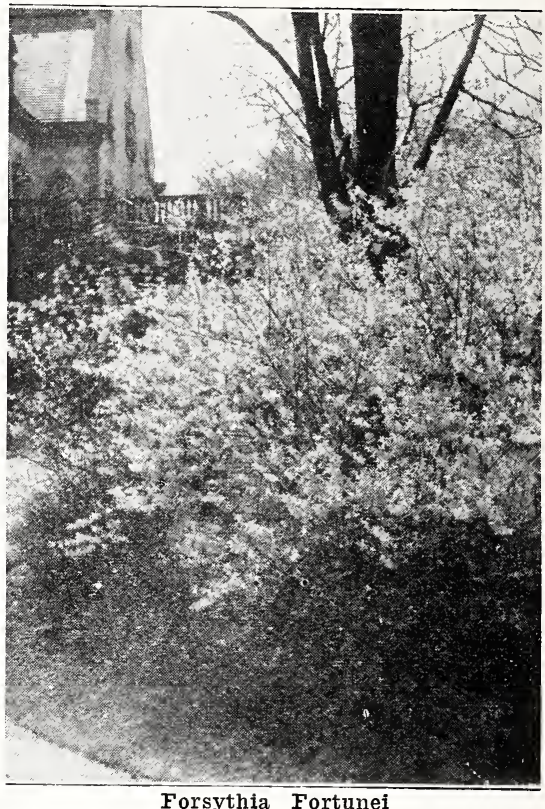

DEUTZIA GRACILIS-Dwarf drooping branches a $r e$ growing, dense, bushy: it wreathed with pure white blossoms in May. It is fine as a border plant, and ideal for single plants where a low shrub is wanted.

12 to $15 \mathrm{in}$.

$.50 \mathrm{C}$

15 to $18 \mathrm{jn}$.

$.60 c$

\section{Forsythia Fortunei}

FRINGE, PURPIE (Smoke Tree)-A bush 10 ft high with simple obvate leaves and brown bark, flowers purple on long panicles. 18 to 24 in. 2 to $3 \mathrm{ft}$. $\$ 1.00$

FORSYTHIA FORTUNET-Few if any, of the spring-flowering, hardy shrubs can surpass the splendor and brilliancy of the Forsythia. Both the grace and beauty give them a prominent place in all shrub plantations. Of upright vigorous growth, foliage rich, dark green and lustrous. Flowers brilliant golden yellow.

2 to $3 \mathrm{ft}$.

3 to $4 \mathrm{ft}$.

$50 \mathrm{C}$

FORSYTHIA INTERIMETA - A handsome upright bush with deep green foliage turning to a purplish tint in the autumn. It is the first to greet the spring time with its shower of golden yellow trumpetshaped flowers that appear in advance of the leaves.

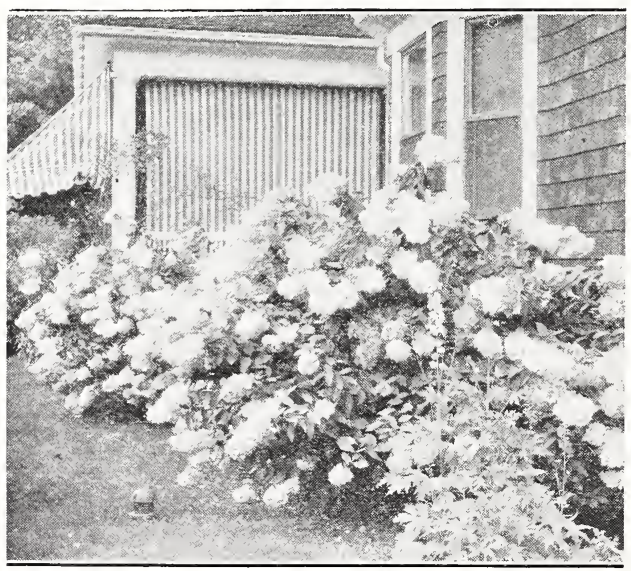
2 to $3 \mathrm{ft}$ $5 n c$ 3 to $4 \mathrm{ft}$. $60 \mathrm{c}$

\section{FORSYTHIA SUSPEN-}

SA-This variety has a peculiarly beautiful Croop. Pretty bellshaped flowers before the grass grows or the leaves start in the eaily spring. Very hardy, should be in every collection of shrubs.

2 to $3 \mathrm{ft}$..................50 3 to $4 \mathrm{ft} . \quad \ldots \ldots \ldots \ldots \ldots . . . . . .60 \mathrm{c}$

HYDRANGEA，F. G. A beautiful, tall shrub bright green foliage; flowers in Aug. and Sept. Beautiful as a border.

12 to $18 \mathrm{in}$................40 18 to 24 in. ..............50 2 to $3 \mathrm{ft}$..................60

Hydrangea, P. G. 


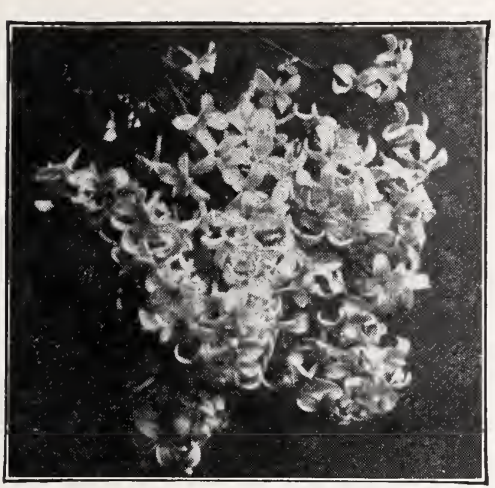

Lilacs

HYDRANGEA (Continued) HYDRANGEA (Hills of Snow) -Almost all of the flowers are sterile. Very showy variety, excellent for borders.

2 to $3 \mathrm{ft}$.

.500 3 to $4 \mathrm{ft}$

$60 \mathrm{c}$

HYPERICUM ((iold Flower)Late fall bloomer and is hishly prized for its great masses of golden flowers. Will grow on partial shade and very poor soil. 12 to 18 in. ........................... $60 \mathrm{c}$ 18 to 24 in.

IRRRIA, yellow-

12 to 18 in.

$50 \mathrm{c}$ 18 to $2 t$ in -60

KERRIA (Kerlioids) White-It grows from four to eight feet high and as broad as high. Very attractive. Flowers appear in early June in great abundance.

2 to $3 \mathrm{ft}$.

$.50 \mathrm{c}$

3 to $4 \mathrm{ft}$.

60 c

IILAC (Com. purple and white)-A very free bloomer; has small leaves and a rather spare foliage. By some is liked better than the hybrid lilac. It is a very pretty flower.

18 to 24 in.

$50 \mathrm{c}$

2 to $3 \mathrm{ft}$.

$60 \mathrm{c}$

IILAC (Persian)-Grows 4 to 6 feet high, foliage small and flowers a bright purple borne profusely; very fine. One of the most fragrant flowers known.

18 to 24 in.

$60 \mathrm{c}$

2 to $3 \mathrm{ft}$.

$75 \mathrm{C}$

IIIACS, Grafted, Named sorts-

2 to 3 ft.

3 to $4 \mathrm{ft}$

1.40

HONEYSUCKIE (Tart., red, and pink)-All the honeysuckle bushes are similar as to habits and foliage. They grow 6 to 10 feet in height. Any of them stand pruning well. The beautiful pink blooms are fragrant and delicate followed by red berries which are borne in clusters.

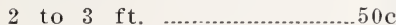

3 to $4 \mathrm{ft}$.

$60 \mathrm{c}$

HONEYSUCKLE (Morrowii) White)-This bush has a slight droop. It is a sturdy, strong grower. Its white blooms are followed with red berries. It is as good as the other varieties. A tall hedge or screen of honeysuckle bushes in assorted colors of flowers and berries is nice indeed where same can be used.

2 to $3 \mathrm{ft}$. $.50 \mathrm{c}$ 3 to $4 \mathrm{ft}$. $.60 \mathrm{c}$

POTENTIIA (Fruiticosa) -Yellow 12 to 18 in. ......60 18 to 24 in. ..................... $75 \mathrm{c}$

PHIIADELPHUS ( Mock Orange) - A sweet-scented dwarf form of Syringa. Beautiful, creamy white flowels with yellow centers in June Adapted for planting in front of taller shrubs. Hardy.

2 to $3 \mathrm{ft}$. $.50 \mathrm{c}$ 3 to $4 \mathrm{ft}$. $60 \mathrm{c}$

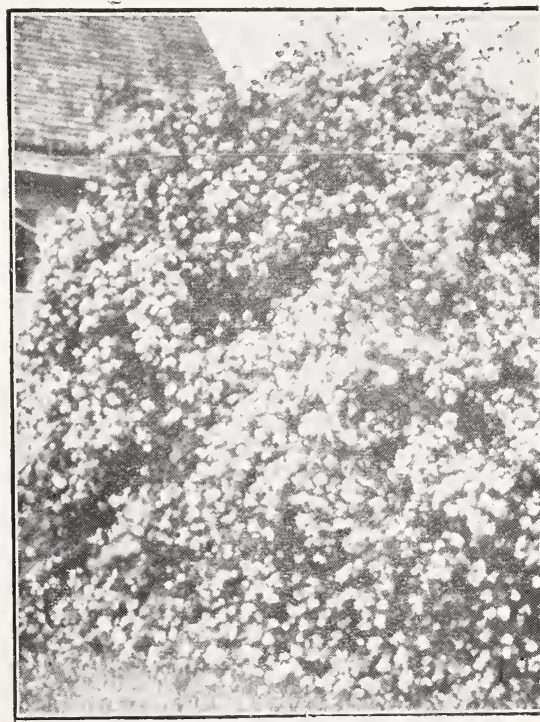

Philadelphus (Mcck Orange) 


\section{PHIL ADELPHUS- (Continued)}

PHILADELPHUS (Coronarius) - $\mathrm{g} \mathrm{r}$ e a $\mathrm{t}$ masses of sweet scented flowers in May and June. Popular for lawn planting and in gardens for several generations and its deserved popularity is increasing. Extremely hardy and vigorous.

18 to $24 \mathrm{in}$.

2 to $3 \mathrm{ft}$. $.50 \mathrm{c}$

PHILAdeLPfus (Lemoinei) - Beautiful creamy white flowers with yellow centers in June, entirely covering the plant. Adapted for planting in front of taller shrubs. Hardy.

18 to $24 \mathrm{in.}$

$60 \mathrm{c}$

2 to $3 \mathrm{ft}$. $75 \mathrm{c}$

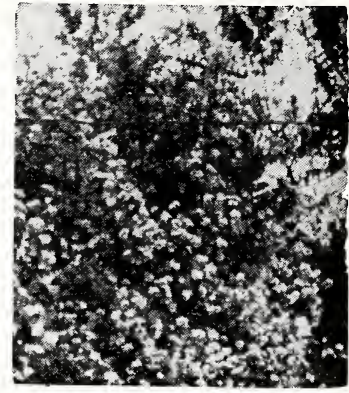

Philadelphus

PHILATELFIUS VIRGINATIS-This is a new and wonderful addition to the Mock Orange family but is far beyond anything in this line that has been brought out in the past. One of the most beautiful shrubs grown and once it becomes known will be planted on every home ground. Large double flowers completely cover the bush in early June.

18 to 24 in.

2 to 3 ft.

$\$ 1.25$

PHILADELPFUS AURFA-Similar to Coronarius except that the foliage is a beautiful golden color.

12 to 15 in.

15 to 18 in.

$60 \mathrm{c}$

18 to 24 iri.

$.75 \mathrm{c}$

PRIVET, IBOTA-Hardy. Grows prettier each year. Being much used. Has a dense, spreading habit. White flowers. Black berries. Fine for large view breaking hedges.

2 to $3 \mathrm{ft}$.

$40 \mathrm{c}$

3 to $4 \mathrm{ft}$.

$50 \mathrm{c}$

PRIVET, VARIEGATED IEAF-12 to $18 \mathrm{in.} \ldots \ldots$ 18 to 24 in.

$50 \mathrm{c}$

RHUS (Glabra)—Tall growing with branching habits; foliage bright green, fading to scarlet in autumn; hlossoms in June, with yellow flowers.

3 to $4 \mathrm{ft}$.

$50 \mathrm{c}$

4 to $6 \mathrm{ft}$.

$60 \mathrm{c}$

6 to $8 \mathrm{ft}$.

$75 \mathrm{c}$

RHUS, A romatica-Spreading in growth: Leaves trifoliate aromatic.

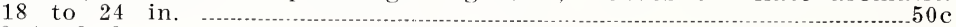
2 to $3 \mathrm{ft}$.

$60 \mathrm{c}$

RHUS (Lacianiata) - This variety with its deeply and finely cut leaves is very handsome, not quite so hardy as some of the other forms and not so tall growing.

3 to $4 \mathrm{ft}$.

4 to $5 \mathrm{ft}$.

5 to $7 \mathrm{ft}$.

$50 \mathrm{c}$ $60 \mathrm{c}$

RHUS (Stag Horn) -Large shrub orows in

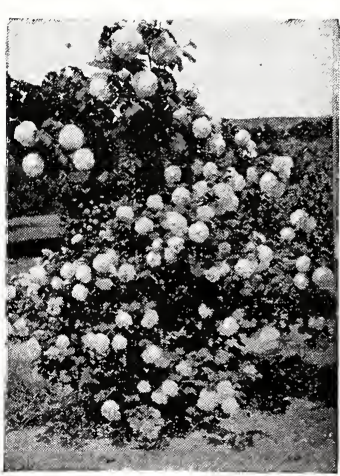
ularly desirable because of its brilliant autum color.

2 to $3 \mathrm{ft}$

-

RUSSI N orIvE-For any one desiring a hedge plant of great merit the Russian Olive will be worth considering. Silvery white leaves make it very attractive.

3 to $4 \mathrm{ft}$

$.50 \mathrm{c}$

4 to $5 \mathrm{ft}$.

$60 \mathrm{c}$

SNOWBERRY (White)-A dwarf shrub with small foliage and small pink flowers in June, followed by great clusters of large white berries that hang on until winter.

2 to $3 \mathrm{ft}$.

3 to $4 \mathrm{ft}$.

SNOWBAIL-Too beautiful and well known to need description. The name "Snowball" describes it exactly. Strong, hardy shrub. 18 to 24 in. ........ $50 \mathrm{c}$ 


\title{
SPIREA
}

All the Spireas bloom extravagantly. This family contains more attractive varieties than any other. They range in height from dwarf to tall, color of blossom from white to red, and period of bloom from early April to August. All the species are very hardy, easily grown.

\begin{abstract}
S P I R $\mathbf{A}$ V A N HOUTTrI-At the head of the list, as it is the most popular shrub knownthe grandest of all the hardy spireas. No one ever forgets the sight of one of these nice shrubs, or a hedge of them when in bloom. Forms a graceful pendulous shrub 4 to 6 feet high, and a fountain of pure white blossoms in May and June.

18 to 24 in ....... $30 \mathrm{c}$ 2 to $3 \mathrm{ft}$........... $40 \mathrm{c}$ 3 to $4 \mathrm{ft}$.............50
\end{abstract}

\section{SPIREA, A N T H} ONY WATERER-

Bright pink. June

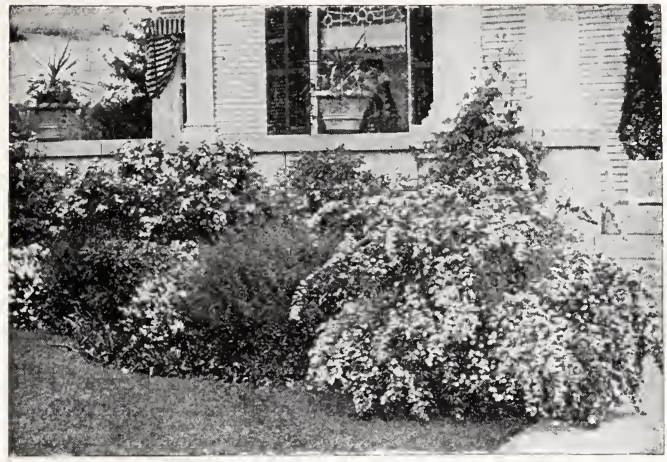

Spirea Van Houttei

and July. A compact low-growing shrub with dense foliage usually deep green with occasional variegated leaves of pink and white on young growth. Flowers are borne in full flat clusters on erect stems. 12 to 15 in. 15 to 20 in.

$40 \mathrm{c}$

SPIREA BUMAIDA-Similar to Anthony Waterer in growth and habit but with light pink flowers. White and pink.

12 to 18 in.

$40 \mathrm{e}$ 18 to 20 in.

$50 \mathrm{c}$

SPIREA FROEBELII-Similar to Anthony Waterer in many respects, but taller. Dense heads of crimson flowers. The new foliage in Spring is red giving the shrub the appearance of being covered with flowers.

12 to 18 in.

$50 \mathrm{c}$ 18 to 24 in.

$60 \mathrm{c}$

SPIREA THUNBERGI-Extra early flowering species. It is spreading in growth with arching slender branches that are a perfect mass of minute flowers followed with exceptionally delicate green foliage. 12 to 18 in.

18 to 24 in.

$40 \mathrm{c}$

2 to $3 \mathrm{ft}$. ..

$50 \mathrm{c}$

SPIREA DOUGLASSI-Very desirable with spikes of deep pink flowers July, August.

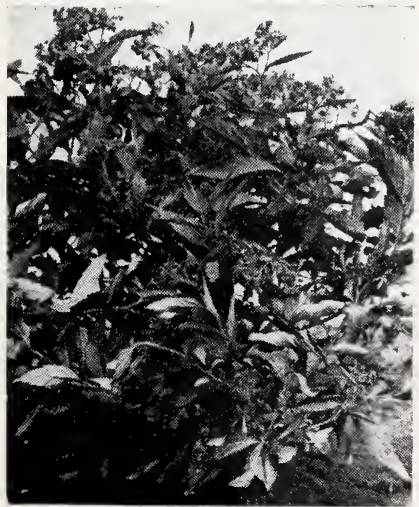

Spirea Anthony Waterer
Pink 18 to 24 in. ........................ $40 \mathrm{c}$

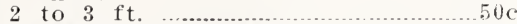
SPIREA OPUIIFOIIA-Ornamental, bright foliags and double white flowers in Jume. Old flower heads turn to dark red. Striking and showy at all seasons.

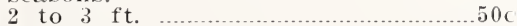

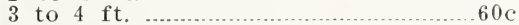

Opulifolia, Aurea-Same as above except that foliage is golden.

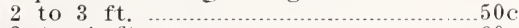
3 to $4 \mathrm{ft}$.

SPIRIA, COIISA AIBA-A splendid companion to the Spirea, Anthony Waterer. Of dwarf, dense growth, with white flowers. In bloom all summer.

12 to 15 in. ................................... 15 to 20 in. ................................... $50 \mathrm{c}$

SPIREA SALICIFOIIA-Willow-like foliage, shiny and attractive. Crowded with panicles of pink flowers.

White, 2 to $3 \mathrm{ft}$. $50 \mathrm{c}$

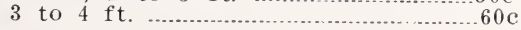


TAMARIX HISPIDA-Grows 8 to 10 feet high at maturity and stands pruning well. A very handsome and distinct variety with dense bluish foliage. The delicate soft sprays of Carmine Rose blossoms are exceedingly attractive. Blooms in September when few other shrubs are in bloom. Stands winters well; should be more generously planted.

2 to $3 \mathrm{ft}$.

$60 \mathrm{c}$

3 to $4 \mathrm{ft}$. $.75 \mathrm{c}$

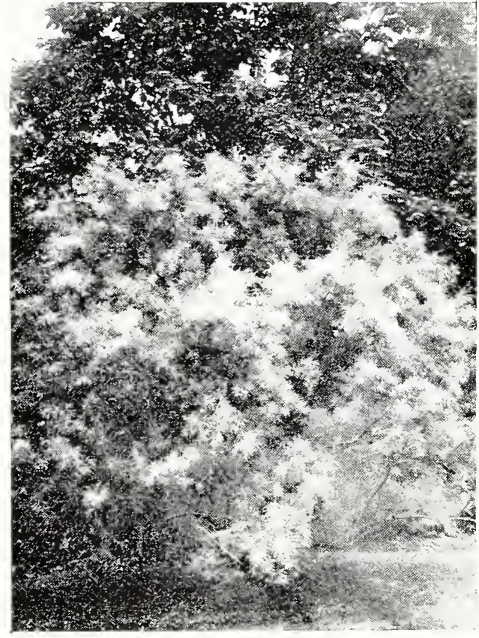

Tamarix

TAMARIX AMERUSF - These plants are very beautiful all the year, in winter for their coloring of the bark and in summer for the light green, feathery foliage and large loose panicles of flowers.

2 to $3 \mathrm{ft}$.

$50 \mathrm{c}$

3 to $5 \mathrm{ft}$. $.65 \mathrm{c}$

VIBURNUM (High Bush Cranberry)-Ornamental as well. as useful; its white flowers are followed by clusters of red berries resembling cranberries, which remain on the bushes all winter.

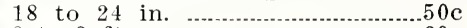
2 to $3 \mathrm{ft} . \ldots . \ldots 0 \mathrm{c}$

2 to 4 ft.

VIBURNUIV IANTANA-Upright shrub with large filmy white flowers in May followed by pink berries which later turn red, then black. Heart-shaped crinkly foliage, light green above and silvery heneath.

18 to 24 in.

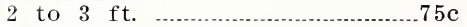
VHBURINUIM DENTATUM-Bright green heart shaped leaves turning to purple and red. Flowers in May and June of creamy white.

18 to 24 in. $50 \mathrm{c}$

2 to $3 \mathrm{ft}$.

$60 \mathrm{c}$

WFIGEIA, ROSEA-The most popular of all the Weigelas. Foliage is a deep green and bush is a vigorous grower. Flowers are a bright rose color, appearing in greatest abundance in June, and more sparsely at interials throughout the summer.

18 to 24 in. $40 \mathrm{c}$

2 to $3 \mathrm{ft}$.

3 to $4 \mathrm{ft}$.

$60 \mathrm{C}$

WEIGEIA CAINDIDA-Flowers are pure white; produced in great profusion in June; also more or less all summer.

18 to 24 in

2 to 3 ft.

$.50 \mathrm{c}$

3 to $4 \mathrm{ft}$. ....................

WEIGEIA EVA RATBRA-A dark red flowering shrub coming into blossom just after the spirea Van Houtte. It has little bell shaped flowers of dark red. Very showy and one of the best shrubs for planting any place you would want a shrub to be. Can be trimmed or cut back at any time and kept the size desired. IVill continue to blossom throughout the entire summer.

18 to 24 in.

2 to $3 \mathrm{ft}$.

$60 \mathrm{e}$

3 to $4 \mathrm{ft}$. $.75 \mathrm{c}$

WEIGEIA VARIRGATED-Should be in every collection. Its variegated foliage, silver yellow and green leaves with pink flowers have won it much fame and popularity. 18 to 24 in.

2 to $3 \mathrm{ft}$.

$60 \mathrm{c}$

3 to $4 \mathrm{ft}$.

$85 \mathrm{c}$

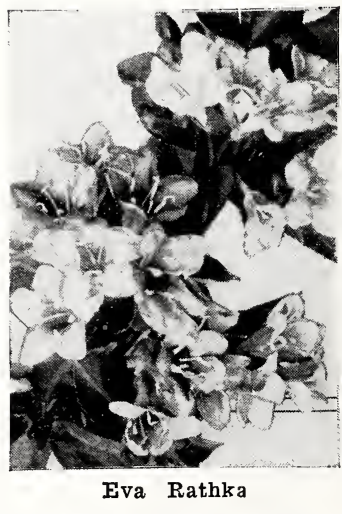

By the proper selection from the varieties listed in this catalog, the home maker can have interesting specimens in their most perfect state, interesting to himself and the passerby at all times of the year. 


\section{CLIMBING VINES}

Without climbing vines many homes wouid lack much of their beauty. Then it follows that niany homes that are still dull and unattractive can be made beautiful from early spring, when the tendrills of hardy climbers take on new life, till winter comes again.

CIEMATIS JACK MANII-One of the best known of all the clematises. The velvety-purple flowers, when expanded, are four to six inches across, very velvety and distinctively veined.

2 yr. No. 1

$85 c^{\circ}$

CIEMATIS, HENRYII-Large flowering white Clematis. A strong grower and free bloomer.

2 yr. No. 1

$.85 \mathrm{c}$

CLEMATIS MAD. ANDRE-This is the nearest approach to a bright red Clematis. It is a very free bloomer and very satisfactory.

2 yr. No. 1

$85 \mathrm{c}$

CIEMATIS PANICUIATA - Thîs Clematis is by far the most popular of all the species. It is extremely showy when covered with the small white fragrant flowers, which appear late in the season. Beautiful, shiny, green foliage.

2 vr. No. 1

$50 \mathrm{c}$ 3 yr. No. 1

$60 \mathrm{c}$

HONEYSUCKLE (Halls Japan)-Honeysuckles are well adapted for the covering of walls, arbors, etc., are very ornamental as the leaves remain on during the winter. The flowers are white, turning to yellow and are very fragrant.

2 yr. No. 1

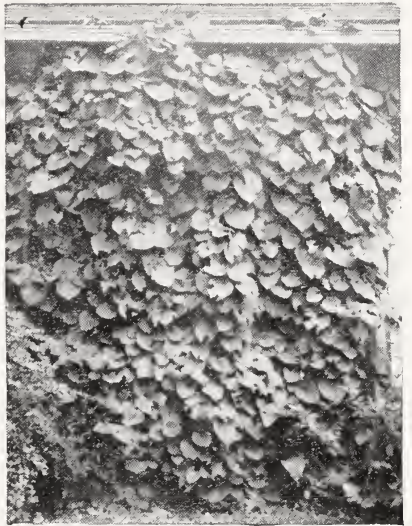

Dutchman's Pipe

WISTARIA (purple)-This is one of the best and commonest of hardy climbers. Drooping clusters of purplish, pea-shaped flowers. 2 yr. No. 1

$60 \mathrm{C}$

SCANDENS (Bittersweet) - Hardy ornamental vine. Very effective by their bright-colored fruit remaining usually throughout the winter. They grow in almost any soil and situation. Fruit is about onehalf inch in diameter, orange-yellow, with crimson seed. 3 yr. No.

DUTCHMAN'S PIPE-A very vigorous growing vine with large deep green leaves and green twigs, producing in abundance a purplish blossom much resembling a pipe. Grows very dense.

3 yr. No. 1

$90 \mathrm{c}$

IVY (Engleman's)-Like the Boston Ivy only that it has a larger leaf and stands out more from the wall. It makes a quicker growth.

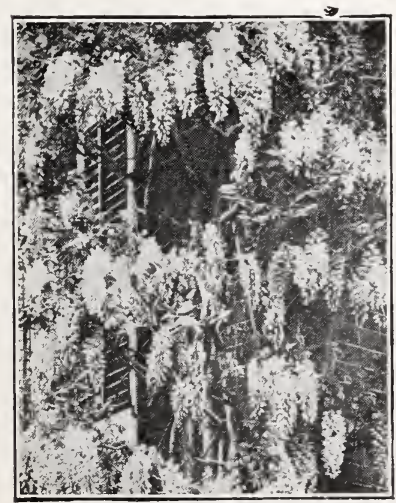

Wistaria It will cling to brick and stone.

$50 \mathrm{c}$

IVY (Ampelopsis) (Boston Ivy) - Once established grows rapidy and will stay indefinitely, needing only an occasional trimming to keep it within bounds. It is not attacked by disease or insects and the foliage is not injured by the smoke and dirt of cities. The glossy leaves turn to $a$ brilliant orange-scarlet in the fall.

2 yr. No. 1

3 y

$65 \mathrm{c}$

FUONYMOUS RATCANS t haldy evelgreen vine, or will form a spreading shrub where it can not climb. Valuable for covering graves, especially desirahle for shady locations.

2 vr. No. 1

JAPAN SPURGE-For borders or shady places.

Each

Per 10 


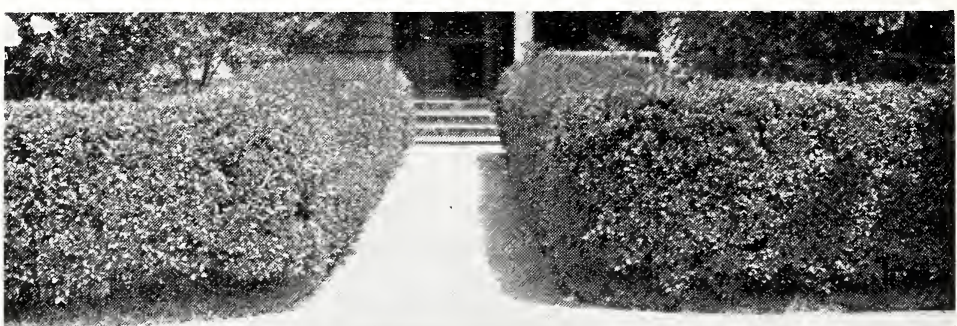

\section{HEDGE PLANTS}

A small amount of money invested in beautiful hedges will add more value to a country or city home property, dollar for dollar, than any other similar investment. A hedge planted about the borders of a lawn will transform a heretofore bare looking spot into a place of beauty, and you can keep it low or let it go high, as a screen. City lots may be divided by Hedging with fine effect.

BAREFRRY, THUNBFRGII-We consider this the best hedge plant in existence. It is beautitul throughout the year; its abundant crop of bright red berries makes it even more attractive in the winter than the summer. Its compact growth and thorny branches make a defense hedge that will turn cattle after five years' growth. As an untrimmed hedge it requires no attention except an occasional cutting of a few straggling branches. The natural growth is so dense and even that it forms a perfect hedge without shearings, but if a formal hedge is desired, it can be made so by shearing; hardy, of easy culture, and will grow in any soil or situation. For a hedge, plant in single row, 15 inches apart.

2 yr. $12-15$ in.

Each 100

3 yr. $18-20$ in.

$20 \mathrm{c} \$ 15.00$

4 yr. 24-30 in.

Barberry, Box, 4 yr 15-18 in. ..................................................

PRIVET, AMOOR RIVER-Hardiest of all hedge plants. Beautiful upright growth and makes a very compact beautiful hedge. Sheds its foliage a little earlier than California Privet.

2 yr. $12-18$ in.

Each 100 2 yr. $18-24$ in. $10 \mathrm{c} \$ 8.00$

BARBERFY, Red Ieaf-Similar in all respects to the green leaved Japanese Barberry which is so popular for mixing in a shrubbery border as single specimens or for planting in clumps on the lawn, as well as for foundation plantings and for hedge, but the foliage of this new variety is of a rich, lustrous bronzy red, similar to the richest brilliant and red leaved Japanese Maple. As the season advances it becomes more gorgeous and in the fall its foliage changes to vivid orange scarlet and red shades. To best develop its brilliant coloring, plant in full exposure to the sun.

2 yr. No. 1

2 yr. No, 2

3 yr. No. 1

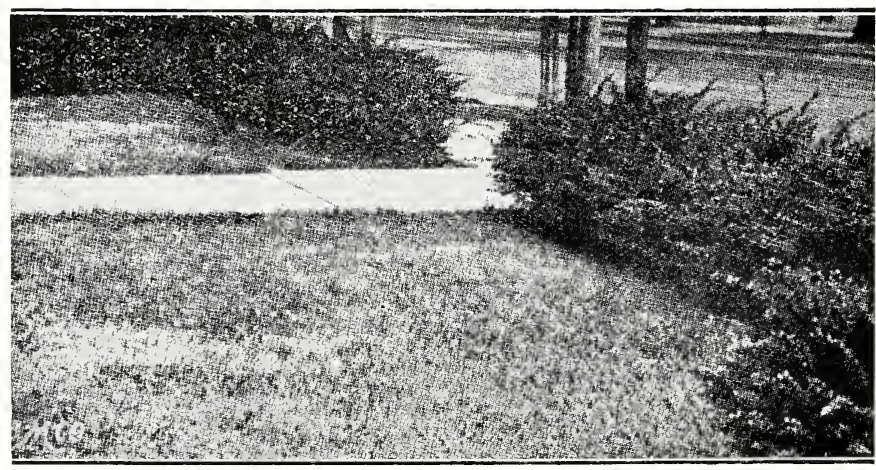




\section{ROSES}

Roses thrive best in a medium light clay soil. Before planting prepare the soil by spading and thoroughly working over to a depth of about 18 inches, fill in well-rotted stable manure while spading and work it carefully into the soil. After the plants are set for best results cut all branches back to within 3 or 4 inches of the top of the ground. The new growth coming out will make a much nicer head than if the plant were not pruned, and the bushes will bloom all the better.

Rosa Rugosa, Rubra and White single, 65c each, $\$ 5.00$ per 10.

\section{Rugosa Roses}

R U G O S A, GROOTEN. DORT-Bud small, flower open, double, borne in clusters on average length stems; very lasting; slight fragrance. Color bright red, edges of petals serrated like a carnation; disease resistant. Vigorous grower of bushy habit, bearing a profusion of bloom from June to October. Very hardy.

RUGOSA, HANSA-Large double, reddish violet. Rampant growth. RUGOSA, CONRED F, MEYER-Flowers large, double cup-shaped. Color deep, bright, vivid, intense pink, with the penetrating fragrance of the old June Roses.

RUGOSA, SIR THOS. IIFTON-The best pure white Rugosa Rose. Strong and vigorous; grows four feet high. Flowers perfectly double, pure snow-white. Fragrant. Blooms more than once during the season. Each 75c; Per 10, $\$ 6.50$.

\section{CLIMBING ROSES}

Price, 2 yr. No. 1 Each, 60c; Per 10, \$5.00. CRIMSON RAMBLER-Will attain a height of 10 to 20 feet in a season; produces a marvelous profusion of rich and glowing crimson clusters during June and July. It is the supreme novelty among climbers and the forerunner of the splendid array of "Ramblers" now embraced in this class.

DOROTHY PERKING-A most beautiful shell pink. The flowers are borne in large clusters of small double bloom and very sweet scented.

EXCEISA-A sensational new hardy climbing rose. Flowers are very double, produced in immense trusses of thirtv to forty flowers to each truss. Color intense crimson-new and distinct. Lasts a lifetime

\section{IIST OF CIIMBING ROSES}

American Beauty, Pauls Scarlet, Dr. Van Fleet. American Pillar, fold Finch. Gardenia, Silver Moon, Flower of Fairfield. 2 yr. No. 1, Each $65 \mathrm{c}^{\prime}$; Per $10, \$ 6.00$.

IIST OF HYERID PERPETUAL AND TEA ROSES

American Beauty, F. K Drusks, Gen. Jacquiminot. J. B. Clark, M. P. Wilder, Mrs. J. Laing, Paul Nevron. Prince Camille de Rohan, Soliel de'Or, Ulrich Brunner, *Columbia, *Gen. McArthur, K. A. Victoria, *Lady Hillingdon, Mme. C. 'Testout. *Mme Edouard Herriott. *Ophelia, Premier, Red Radiance, Pink Radiance. *Sunburst, *Willowmere. Los Angeles. Each 85c; per 10, \$7.50. Those marked with a star, price each, $\$ 1.00$; per $10 . \$ 9.00$.

\section{BABY RAMBIFR ROSES}

\section{2 yr. No. $1,85 \mathrm{c}$ each; $\$ 7.50$ per 10.}

Ellen Poulson, Baby Dorothy, Mme. Levasseur, Orleans, Katherine Zeimet.

Prairie Rose, 2 yr. 65c each, $\$ 5.00$ per 10. 


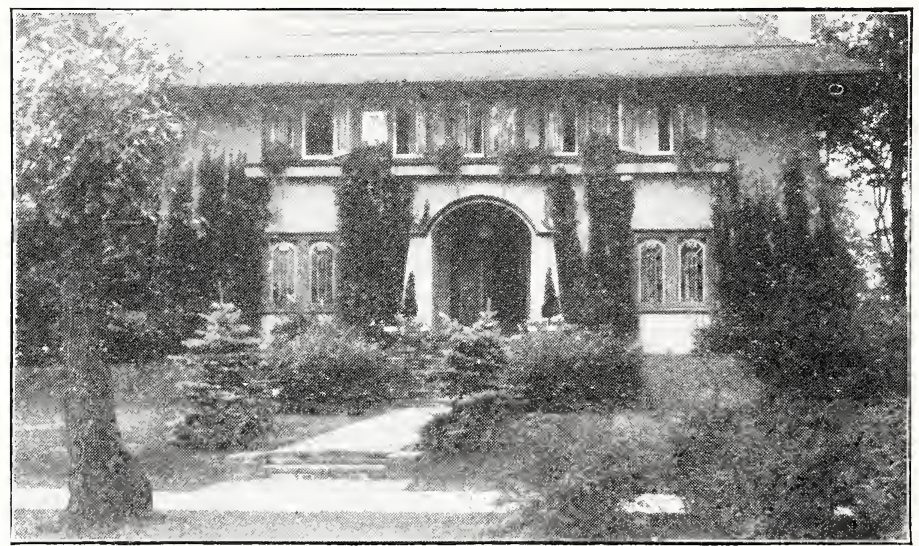

\section{HARDY EVERGREENS}

The Evergreen has vouchsafed man in order to give him to un derstand more fully the Eternal promise of life everlasting. Eversreens typify permanency, defy time and the elements. In the bleak Northern winters the Evergreen stands out in the landscape, fresh green, and full of cheer. An Evergreen inust not have its roots exposed to the sun or wind not even a minute. For this reason large sized trees are dug with a ball of dirt left with the roots and a burlap cloth sewed tightly about it. On smaller sizes of trees we are able to mud the roots heavily and cover with wet moss and cloth.

NORWAY SRRUCF-The best all-around evergreen. The ideal tree for wind breaks. Its close compact growth forms an almost impenetrable barrier to the frigid storms of winter. Norway Spruce deserves to be largely planted on all farms around orchards, barn and cattleyards, poultry-houses and grounds, and wherever protection from cold and storms is needed. At the same time, Norway Spruce is one of our choicest evergreens for ornamental planting.

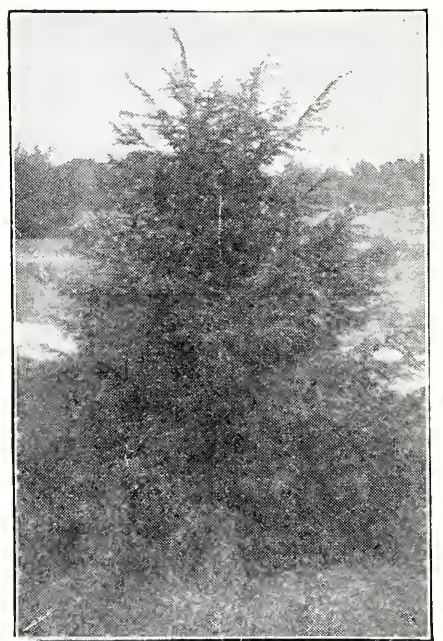

Spruce
$1 \frac{1}{2}$ to $2 \mathrm{ft}$. $\$ 1.50$

2 to $3 \mathrm{ft}$.

3 to $4 \mathrm{ft}$.

4 to $5 \mathrm{ft}$

5 to $6 \mathrm{ft}$.

AMERICAN AREOR VITAE-Very suitable for hedge planting, as it can be kept at any height by shearing. Also widely used in ornamental planting, as they become wonderfully beautiful, if allowed to grow tall.

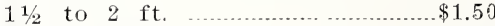

.2 to $3 \mathrm{ft}$. 1.75

3 to $4 \mathrm{ft}$. 3.25

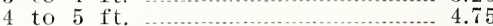

5 to $6 \mathrm{ft}$. 6.50

EYRAMIDAI AREOR VIFAE-EXcellent for group planting in corner's of the lawn. Grow naturally close and compact. Very branchy and feathery. Holds its hright green color all the year.

$11 / 2$ to $2 \mathrm{ft}$. $\$ 2.75$ 2 to $21 / 2$ ft -3.75

$2 \frac{1}{2}$ to 3 ft. ............................... 40 3 to $4 \mathrm{ft} \quad 5.75$

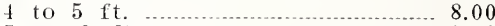
5 to $6 \mathrm{ft}$.

Plant Evergreens for all year round beauty. Use them for foundation plantings, windbreaks, or in the open as specimen ornarnentals. 


\section{EVERGREENS-Continued}

\section{COMPACTA AR-} BO $\mathbf{R}$ VITAE-

Similar in habit to the Globe but of faster growth. Foliage $r$ i $c h$, green. V'ery good $f$ o $r$ foundation plantins, group ing and hedging.

10 to $12 \mathrm{in}$.... $\$ 2.00$ 12 to 15 in.... 2.75 15 to 18 in.... 3.75 18 to 24 in.... 4.75

*GIOBOSA A RB O R VITAE Grows in a round, compact f o r m without shearing. One of our most attractive dwarf trees, and a valuable acquisition to any lawn. Foliage rich green tuning $g$ o l d bronze in winter.

10 to 12 in....\$2.00

12 to 15 in.... 2.75

15 to 18 in.... 3.75

18 to 24 in.... 4.75

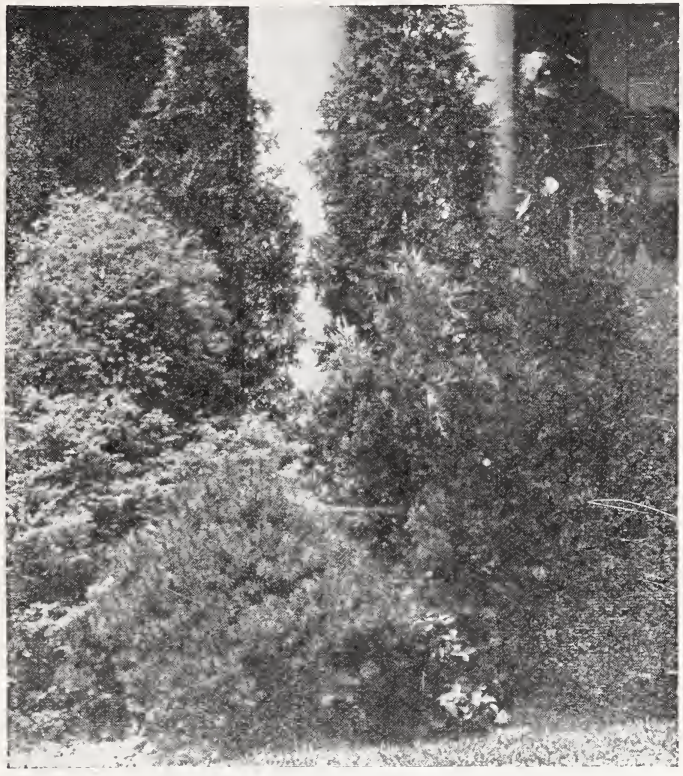

An Attractive Evergreen Planting

GOLIEN ARZOR VITAE-Foliage bright vellowish green all through the winter changing to golden yellow in spring.

12 to 15 in.

15 to 18 in

18 to 24 in

$\$ 1.50$

2 to $21 / 2$ ft.

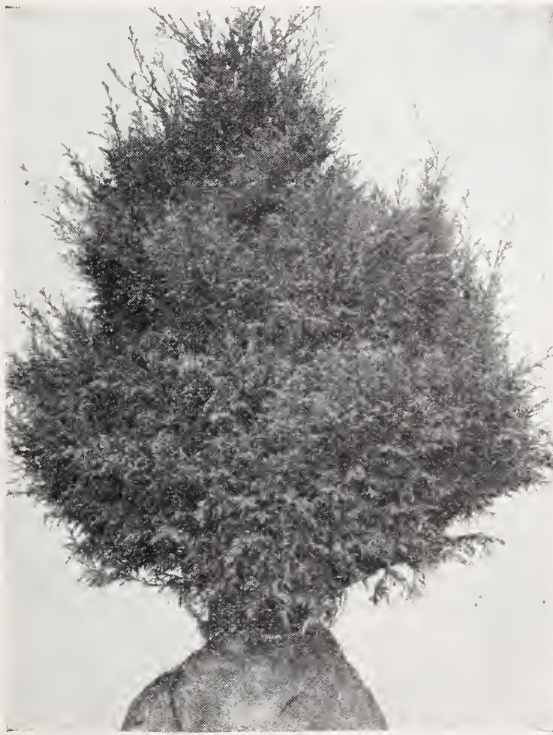

*TOML THUIMB ARBOR VITAE-A dwarf compact growing variety, with finely cut foliage. Suitable where a low specimen is wanted: also useful for hedging and foundation planting.

8 to 10 in.

10 to 12 in. ................. 1.50

12 to 15 in. 15 to 18 in.

CHINESE ARBOR VITAE -A pyramidal tree finally attaining a height of 25 feet, very compact form. Foliage is bright green.

12 to 18 in.

$\$ 1.50$

18 to 24 in. ................... 2.25

2 to $3 \mathrm{ft} . \quad 3.25$

3 to $4 \mathrm{ft}$................... 4.75

$1+05 \mathrm{ft} \quad 6.75$

SIBERIAN ARBOR VITAE -One of the best of the genus of this country; exceedingly hardy, keeping color well; srowth compact and pyramidal.

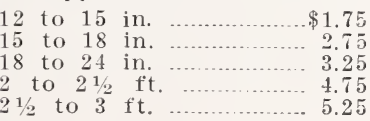




\section{EVERGREENS-Continued}

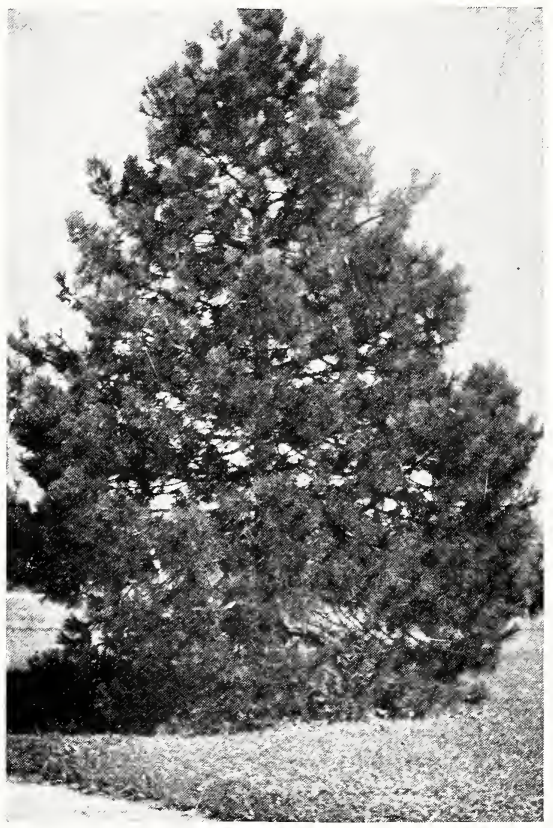

Austrian Pine
*MUGIO PINE- A dwarf evergreen of great beauty. Rarely grows over 10 feet tall with a spread of branches as great as its height. Especially useful for border planting or for grouping with other varieties or single specimens on the lawn. Foliage is medium dark green, thick set, and rather long.

8 to 10 in. ....................... $\$ 2.25$

10 to 12 in. .............................. 2.75

12 to 15 in. ......................... 3.50

15 to $18 \mathrm{in.} . . . . . . . . . . . . . . . . . . . .45$

18 to 24 in. ...................... 6.75

2 to $2 \frac{1}{2}$ in. ................... 8.00

AUSTRIAN PINE- A tall tree, with a broad, ovate crown; leaves in pairs, about four inches long, rigid and very dark green; cones two or three inches long of a glossy yellowish-brown color. A fast growing, dense tree of great adaptability.

2 to $3 \mathrm{ft}$. ........................ $\$ 2.00$

3 to $4 \mathrm{ft}$.

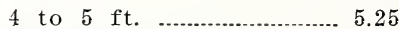

WHITE PINE-Lends itself to every purpose and is one of the most beautiful native evergreens. Foliage long and graceful, of a light green color. Fine for lawn specimens or group planting.

18 to 24 in. $\$ 1.50$ 2.75

2 to $3 \mathrm{ft}$.

3.75

FONDEROSA FINE-A lofty tree from our western coast; hardy quick growing, with long needles of silvery green.

18 to 24 in. .................................... $\$ 2$.

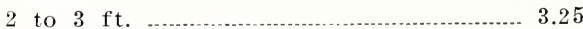

* JUNIPER, SAEINA-A low, wide spreading, thickly branched evergreen shrub rarely $5 \mathrm{ft}$. high. Very attractive with semi-erect branches well clothed with deep green foliage. An excellent tree for rock work or dwarf plantings.

12 to $18 \mathrm{in}$.

$\$ 2.75$

18 to 24 in. 3.75

2 to $2 \frac{1}{2} \mathrm{ft}$. 4.75 $2 \frac{1}{2}$ to $3 \mathrm{ft}$. 6.75 3 to $4 \mathrm{ft}$.

8.00

*JUNIPER, PFITZERS-One of the newer additions to the hardy Evergreen family, but rapidly coming into front rank for ornamental planting. Grows in the form of a low, broad pyramid. Foliage rich tea green.

Price, same as Sabina.

JUNIPER, GIAUCA-A very vigorous variety with silvery blue foliage. This is one of the most beautiful forms of the red cedar, and makes a splendid specimen tree.

$1 \frac{1 / 2}{2}$ to $2 \mathrm{ft}$. $\$ 3.25$

2 to $2 \frac{1}{2}$ ft. 5.75

$2 \frac{1}{2}$ to $3 \mathrm{ft}$. 6.75

3 to $4 \mathrm{ft}$.

8.00

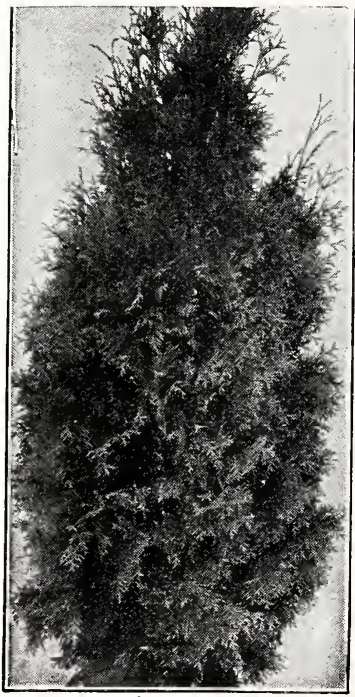

Arborvitae 

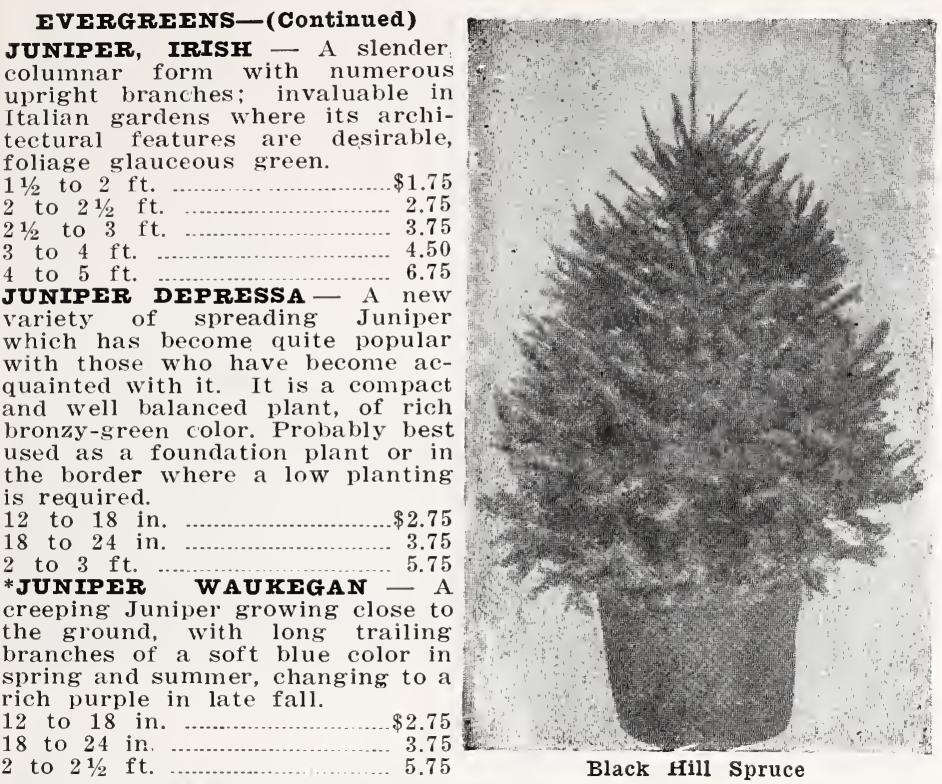

*JUNIPER TAMARISCIFOIIA-A distinct trailing variety of Sabina with very agreeable bright blue green foliage. Is perhaps more svmmertical and dense in habit of growth than other procumbent chinese Junipers.

12 to 18 in.

18 to 24 in.

$\$ 3.25$

2 to $2 \frac{1}{2} \mathrm{ft}$.

4.75

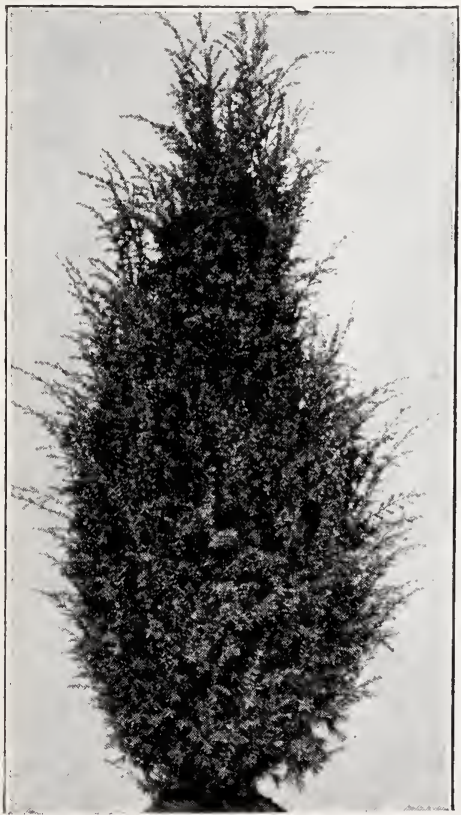

* JUNIPER HORIZONTAIIS-Hardy vigorous grower, main stem lying close to the ground and lateral branches growing upward. Rich in green color. Very hardy. For plant ing on terraces, ranks and other places where a low beautiful evergreen is wanted.

12 to 18 in. ................................. $\$ 2.75$

18 to 24 in. 3.75

2 to $2 \frac{1}{2} \mathrm{ft}$................................ 5.75

JUNIPER VIRGINIA-This bea tiful evergreen attains a height of 100 feet, with conical head and spreading upright branches. Leaves are spiny pointed.

2 to $2 \frac{1}{2}$ ft. ............................ $\$ 3.00$

$21 / 2$ to $3 \mathrm{ft} . \ldots \ldots \ldots \ldots \ldots \ldots \ldots \ldots \ldots \ldots . .5 .50$

3 to $4 \mathrm{ft}$.................................... 5.75

4 to $5 \mathrm{ft}$.

5 to $6 \mathrm{ft}$..................................... 8.00

JUNIPER SIIVER-Much like Red cedar in habit of growth but has a decided bluish-gray cast to the foliage. New growth is quite silver in color. Slow growth makes it very desirable for many uses.

2 to $3 \mathrm{ft}$. ................................ $\$ 3.75$

3 to $3 \frac{1}{2}$ ft. ................................. 6.75

$31 / 2$ to $4 \mathrm{ft}$. ................................... 7.75

SPRUCE (Black Hill)-Dark green perfectly hardy, very compact, the best for general planting.

12 to 18 in. .............. $\$ 2.75$

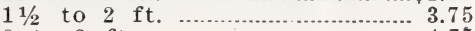

Juniper

2 to $3 \mathrm{ft}$. 
SPRUCE (White) - A very ornamental tree similar to the Norway Spruce. One of the best for cold climates. Is an upright, compact grower, and retains its branches to the ground. Can be distinguished by its grayish blue color and quick growth.

12 to 18 in. .......................... $\$ 1.75$

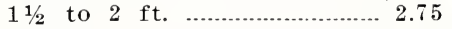

SPRUCP (Englemann)-Is a tree of singular beauty. The strictly pyramidal outline, with the branches closely arranged in circles and maintained to the base, renders it particularly desirable for ornamental grounds. 12 to 18 in. ......................... $\$ 2.75$ $1 \frac{1}{2}$ to $2 \mathrm{ft}$.

3.75

RETINOSPORA, PIUMOSA Plume like cypress. The favorite for hedges, or extensive plantations, yet pleasing as single specimens. With dense, yet fleecy light green foliage.

12 to 18 in.

$1 \frac{1}{2}$ to $2 \mathrm{ft}$.

2 to $3 \mathrm{ft}$.

$\$ 2.75$

RETINOSPORA, P I U M O SA A UREA-Golden yellow foliage,

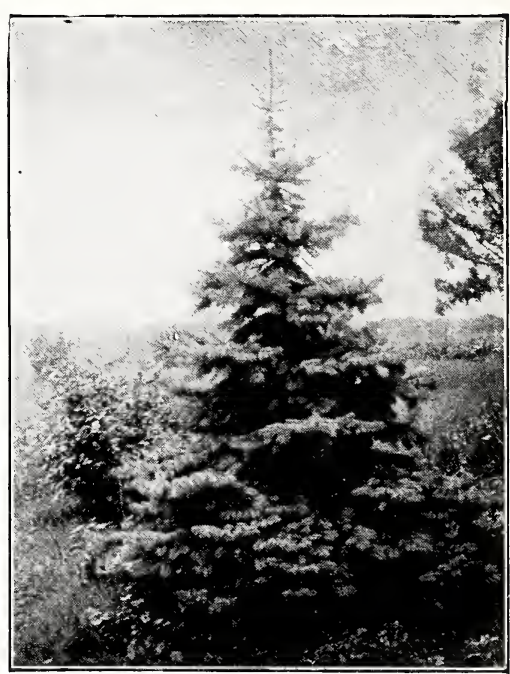

White Spruce

soft and plume like. Very attractive in spring and summer. A pleasant color contrast when planted with other evergreens.

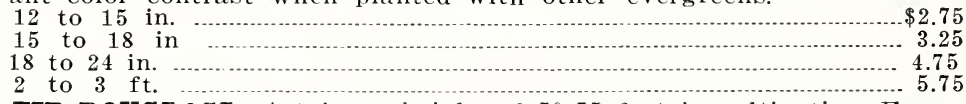

FIR DOUGIASS-Attains a height of 50-75 feet in cultivation. Forms a pyramidal tree of dense and graceful habit. Very hardy and one of the best ornamental conifers.

18 to 24 in.

$\$ 3.25$

2 to $21 \%$ ft.

$2 \frac{1}{2}$ to 3 ft. $\ldots$

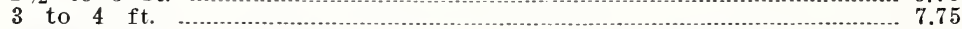

HEMIOCK (Canadensis)-Beautiful, free, drooping trees, but may be used as a tall hedge; delicate, dark green foliage, the rich color being retained all winter.

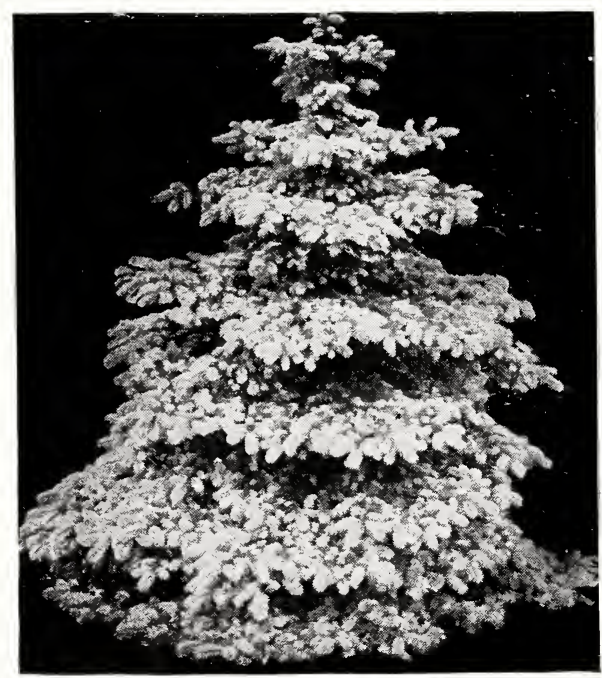

Colorado Blue Spruce
12 to $18 \mathrm{in}$. ............. $\$ 2.75$ 18 to 24 in. ................ 3.75 2 to $2 \frac{1}{2}$ ft. .............. 5.7 อ

COIORADO $B$ I $U$ I SPRUCE-A very hardy tree from the Rocky Mountains. Its regular pyramidal shape and beautiful silvery blue foliage are exceptionally ornamental. In all sizes up to 3 to $4 \mathrm{ft}$. Prices ranging on Blues, from $\$ 5$ up owing to size and color. The green at about $1 / 2$ off the price of blues.

TAXUS (Cuspidata Brevifolia) (Dwarf Japanese)-An excellent dwarf Yew, with fine spreading branches and rich green foliage. Retains its fresh color throughout the year. A very handsome hardy variety. 12 to 15 in. .............. $\$ 3.25$ 15 to 18 in. ................ 4.75 *Trees that the measurement is made across (or spread) and not upright 


\section{GLADIOLUS}

ANNA EBERIUS-Dark velvety purple, throat deeper.

AITAIR (1916. 62 days. Rating 90)-Extra tall, of finest salmonsaffron. A grand color. At the A. G. S. show, Rochester, N. Y, this variety won the A. G. S. Trophy for best corsage bouquet also Trophy for best Plateau Basket.

BUCKFY (1921. 76 days. Rating 90)-Very large, massive bloom of fine rose-pink color with tint of old-rose at edge.

BYRON I. SMITH (1917, 76 days. Rating 94)-One of the very best. Most refined lavender-pink on white ground. Exceedingly fine as a cut flower. Color equal to a very choice cattleya orchid.

CRINKIES (1916. 92 days. Rating 92)-Deep peach blossom pink. Intensely ruffled.

F. J. SHAXIOR (1918, 71 days. Rating 95)-Tall, very strong plant and large blooms. A beautiful, pure, deep, rose-pink.

GOV. HANIFY (1915. 63 days. Rating 92)-Tall, showy, early, rich cardinal-red, with deeper throat color. First-class bleeding and cutflower variety.

HAILFY-Delicate salmon-pink, with a slight roseate tinge, the lower petals bear a creamy blotch with a stripe of bright red through the center.

SUIPHUR GIOW (1921. 73 days. Rating 90)-A beautiful shade of sulphur-yellow. Many expanded, intensely ruffled flowers at a time. JOHN T. PRICE (1922.83 days. Rating 92)-An exceptionally colored variety and very beautiful. A sort of mahogany-brown with remarkable yellow bordered dark mahogany-brown throat. In a class by itself and should be in every collection.

BIACK PANSY (1915. 77 days. Rating 91)-Of richest dark-red. Beautiful pansy-like throat. Extra. A general favorite.

INDIAN MAID (1922. 82 days. Rating 90)-Tall plant and fine stem. Flowers of beautiful peach-blossom pink with beautiful deeper throat. Very choice and distinct.

MRS. FRANK PENDLETON (1915. 70 days. Rating 97)-Bright rosepink on a pure white ground. A giant blotch of richest carmine-red on lower petals. No grander variety in existence. Awarded highest honors at the American Gladiolus Society, Mass. Horticultural Society, and many others.

MARY PICKFORD (1915, 69 days. Rating 94)-An extraordinary flower and spike of most delicate creamy-white. Throat finest, soft sulphur-yellow. Stem and calix also white. Was awarded Certificate of Merit by Royal Horticultural Society, London, Aug. 10, 1920 ; also First Class Certificate of Merit by North Short Horticultural Society. Manchester, Mass., summer of 1919, and winner of hundreds of other awards. Awarded first prize as best cream colored gladiolus without marking, at A. G. S. show, Rochester.

RUTH HUNTINGTON (1923, 82 days. Rating 92)-Beautiful violet lilac with deeper lilac markings on lower petals. Large, strong plant with tall, fine spikes. A general favorite.

ROSE GIORY (1916. $7 €$ days. Rating 94)-A very large and beautiful ruffled variety. Purest rose-pink color. Leeper in throat. Extra fine. Winner of hundreds of awards.

PURPIE SPOT (1918. 80 days. Rating 90)-Large, violet-red with very conspicuous dark blotches. Early, showy.

SCARIET PRINCEPS* (1917. 71 days. Rating 90)-Six or more massive Princeps-like blooms open at a time. Throat a little deeper. Blooms set close. An extra-ordinary, distinct and massive spike. Won a first prize at A. G. S. show, Rochester, Aug., 1925. Winner of many other awards.

UHLAN CHIEF (1922. 66 days. Rating 92)-Tall, graceful, slender spike. Flower of most intense brilliant vermilion-scarlet. Lower petals deeper color and beautiful, dark feathered. A magnificent red.

\section{HARDY PERENNIAL PLANTS}

The well arranged Perennial Garden, of whatever size it may be, will bring joy and gladness, all through the spring and summer as you admire the many changes, in shapes, in hues and colors and the gorgeous creations of nature. They are with you each year. However as we expect best results from our vegetable garden when it has been well cared for, so in the flower garden.

You are invited to visit the Nursery, any time during the flower season, and see them in bloom. A good way to select your flowers. TERMS-Our terms are cash with order or will send by Express or Parcel Post, with exchange added. 


\section{HARDY PERENNIALS}

Achilles, The Pearl

Per 10 Per 100

Aquilegia, Columbine (tall growing)

$\$ 1.50 \quad \$ 12.00$

$1.50 \quad 12.50$

Aquilegia, Columbine, med. tall, mixed -

Coreopsis, yellow - .15

Delphinium, Larkspur, Formosum - .20

Delphinium, Larkspur, Belladonna -

Delphinium, Larkspur, indigo blue _-_-_-_-_-- .25

$1.50 \quad 12.50$

1.25

1.50

1.50

Delphinium, Larkspur, Butterfly Dw., dark and light blue

Delphinium, Larkspur, white

Dianthus, Sweet Williams, mixed colors

1.75

1.35

1.35

1.25

1.50

Dianthus, Hardy Garden Pinks _._._._._. .20

Digitalis, Fox Glove, yellow - 20

Digitalis, Fox Glove, pink

Digitalis, Fox Glove, purple

Gillardia, one of the best

Gypsophila, Baby's Breath

Helianthus, Sunflower

Hemorocallis, Lenone Daylily

Hibiscus, Mallow Marvel, red and pink

Hibiscus, Mallow Marvel, crimson eye

Hibiscus, Mallow Marvel, mixed, 3 yr.

Iris, German, six colors

Lupines, Roseus _._._. 20

Lupines, Albus

Linus, Flax Plant, blue

Myosotis, Forget Me Not, blue and white -...- .20

Papaver, Oriental Poppy, red

Phlox, 18 varieties, 1 yr. _-

2 yr. -

Physotegia, False Dragon Head

1.50

1.50

1.50

1.25

1.75

1.25

2.00

2.00

2.00

3.00

1.50

1.50

1.50

1.50

1.50

2.50

2.25

2.75

1.25

1.75

1.75

1.25

2.00

1.75

Rudbeckia, Golden Glow

.20

Sedum, Brilliant

Salvia, Argentea, Silver Sage

Tritoma, Red Hot Poker, 3 yr.

Campanula, Canterbury Bells -

Daisy, Shasta - - yellow, salmon, blood red aid

Hollyhocks, rose, yellow, salmon, blood red and

Ornamental Grass, clumps

Yucea, Filamentosa, 3 yr.

4 and 5 yr.

Hardy Pea, 2 yr.

2.50

1.50

1.30

10.00

.15

1.75

4.00

4.00

4.00

2.00

2.50

\section{A. E. Kunderd Strain Gladioli}

\begin{tabular}{|c|c|c|c|c|c|}
\hline & Each & Per 12 & & Each & Per 12 \\
\hline Byron L. Smith - & .08 & $\$ .75$ & Sulphur Glow & .15 & $\$ 1.50$ \\
\hline $\begin{array}{l}\text { Gov. Haniey } \\
\text { E. J. Shaylor }\end{array}$ & $\begin{array}{l}.10 \\
.10\end{array}$ & $\begin{array}{l}1.00 \\
1.00\end{array}$ & $\begin{array}{l}\text { Butterboy } \\
\text { Anna Eberius, purple }\end{array}$ & .10 & \\
\hline Purple Spot & .10 & 1.00 & John T. Price -- & .08 & \\
\hline Altair & .10 & 1.00 & Pendleton, pink and red & .08 & \\
\hline Uhlan Chief & .10 & 1.00 & America & .08 & \\
\hline Black Pansy & .10 & 1.0 & Halley & .10 & \\
\hline Indian Maid --.-- & .10 & 1.0 & King & .10 & \\
\hline Scarlét Princeps & 12 & 1. & ma & .08 & \\
\hline Rose Glory -.--- & .15 & & Schwaben -- & .10 & \\
\hline Crinkle & .10 & 1.00 & Mixed colors & .06 & \\
\hline Mary Pickford & .10 & 1.00 & Primulinus varietie & & \\
\hline Buckeye & .10 & 1.00 & asst. colors & .06 & \\
\hline & .10 & & s, yellow, red & .20 & \\
\hline
\end{tabular}

Various shades in white and pink, seven shades.

Divided roots, 3 to 5 eyes

$\begin{array}{lll}\text { Deep red } & & 5.00 \\ & & \end{array}$

CANNAS

Spring planting, assorted colors

2.00

Your visit to the nursery will convince you that our evergreens are second to none in the country. Fresh dug, taken in your machine or truck, properly planted and cared for and there is practically no loss. We give you full directions how to plant and care for them. 


\section{A N D S C A P E}

SITUATED not far from your present address is a service of unequalled excellence devoted almost exclusively now to the problems that a legion of you are to ponder in the making of your home beautiful.

Our position in the service of the Home Owner is unique in this particular channel of endeavor, for Nature hath not wrought a single thing of beauty nor has man builded a single monument to our genius that we cannot reproduce for you in your own surroundings, if ample, should you have the desire.

No idea is too extravagant for our operation. No plan is too large for our comprehension. Yet, we are renowned in the landscape trade for the reasonableness of our remuneration. So much so in fact that we are credited with having popularized Home Beautifying with the Poor Renter and the Home Owner of moderate means.

We show herewith just a few glimpses of landscaping. Some of them are rather elaborate. Most of them very common, but all of them delightful in their particular setting. Of course, we have illustrations and information concerning all types of Formal Gardens, Lily Ponds, Perennial Gardens, Annual Beddings, Shrubbery Groupings, Rose Gardens and Evergreen Plantings together with a fund of knowledge to be gained only from years of experience in the trade.

Because we are located so close to you we can serve you with much less expense and trouble than most any other source of supply.

For your convenience a card has been attached that you may fill out and return to us with the indication of your particular interest which in turn will entitle you to any information that we may have covering the subjects entirely free of charge or obligation on your part.

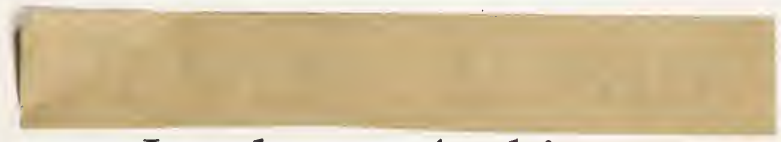

Landscape Architect LAKETON, INDIANA

ASSOCI A TED WI TH THE LAKETON N URSERIES 


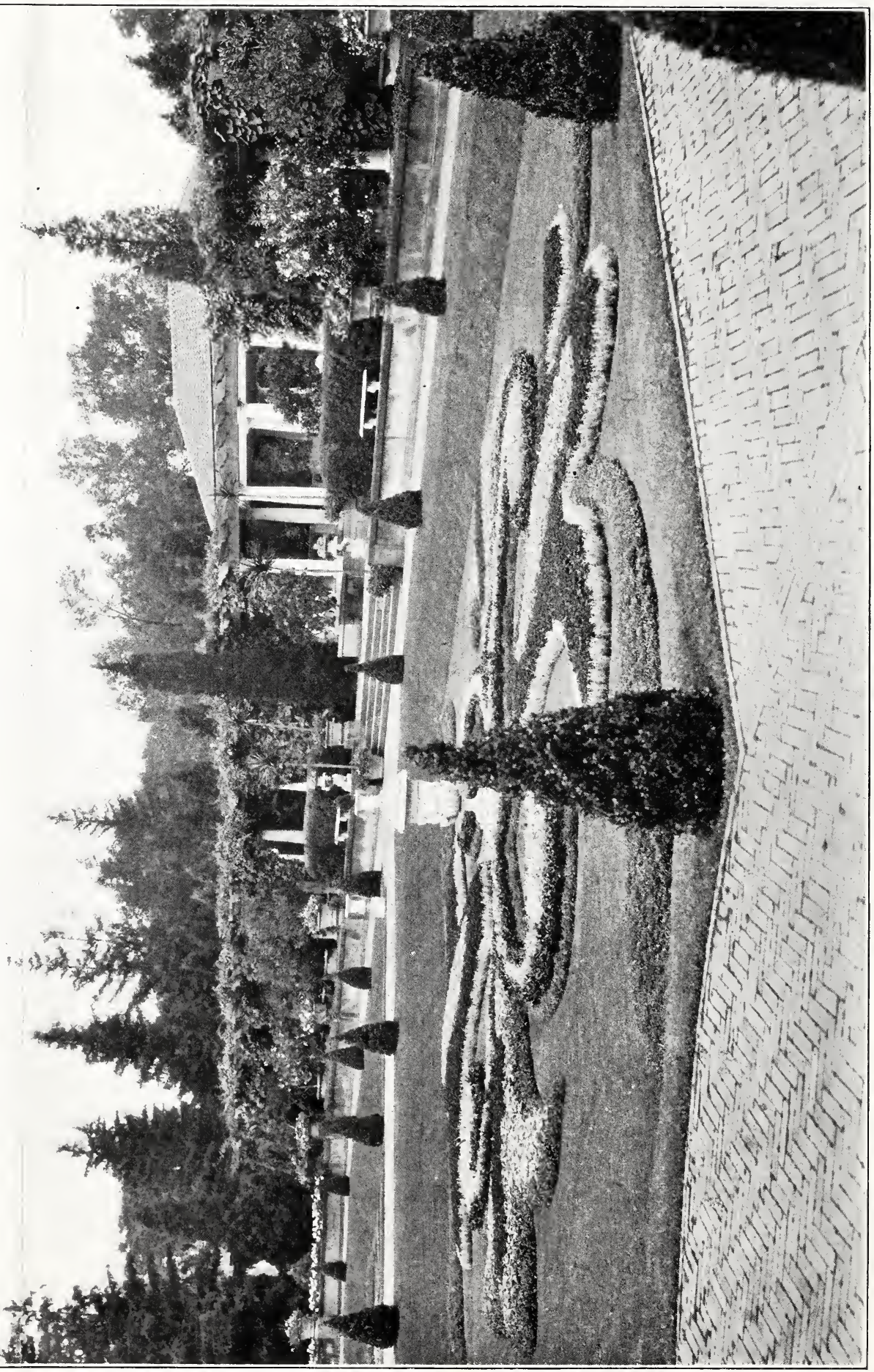


This little planting for a lake cottage has as much attraction for the tired city dweller as the lake itself and best of all it costs less than a good theatre entertainment.

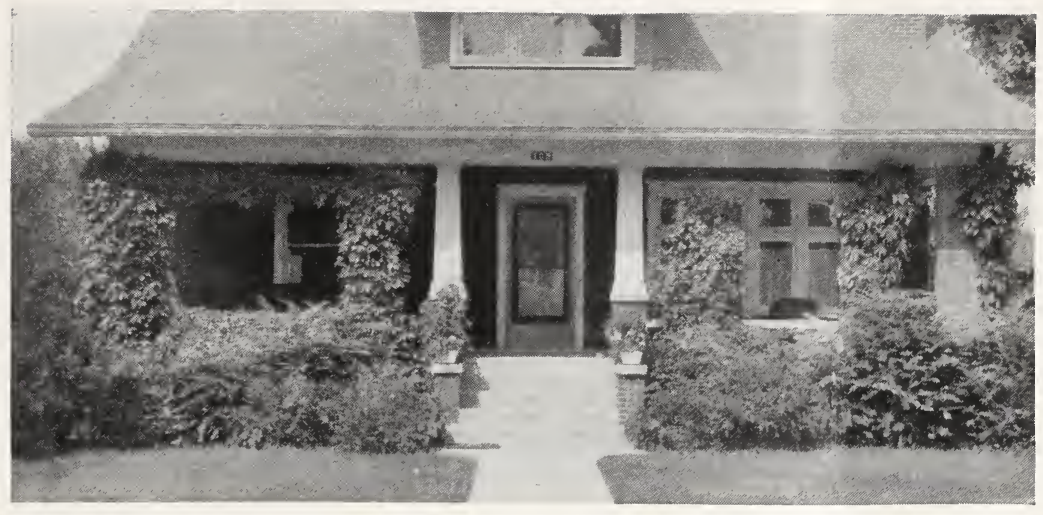

Two score and more years The Laketon Nurseries have been spreading dollars as far as they would go for the large and small buyers of trees and shrubs, and it is a pardonable pride for them to feel that they are pre-eminently foremost today in the service they render to large and small Home Beautifying customers.

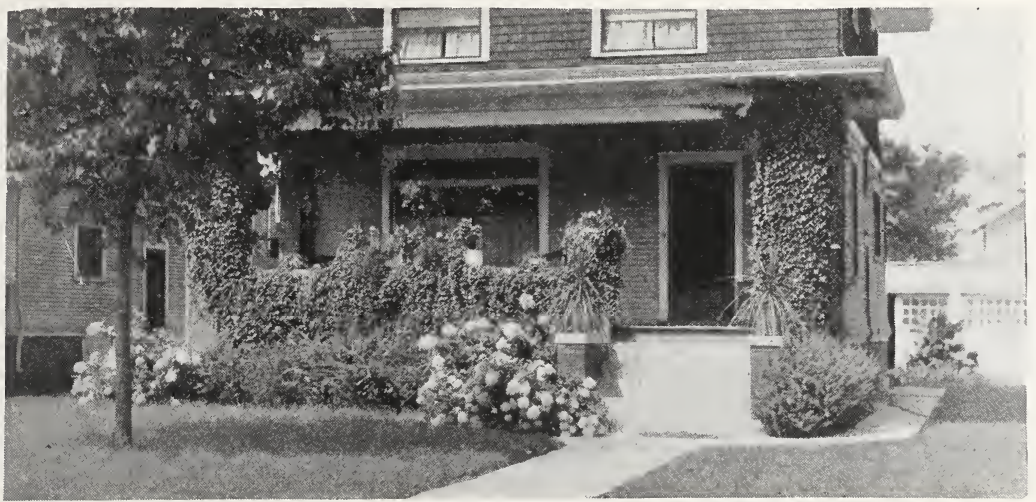

Just a few shrubs in this planting, but they add materially to the value of the property. A good box of cigars would cost more and afford but a whit of the pleasure to be had from the shrubbery.

Landscaping is no longer a closed book to the poor. For only a few dollars property can be improved greatly by the proper arrangement of shrubs and flowers. When you take the flowers and shrubs with their ever attendant beauty and enjoyment away from the home you have no happiness left. We draw blue prints and make all plans for planting.

When properly grouped and selected, roses are a charming addition to the home. We know how to cultivate and grow roses to get their greatest enchantment. Ask us. We'll tell.

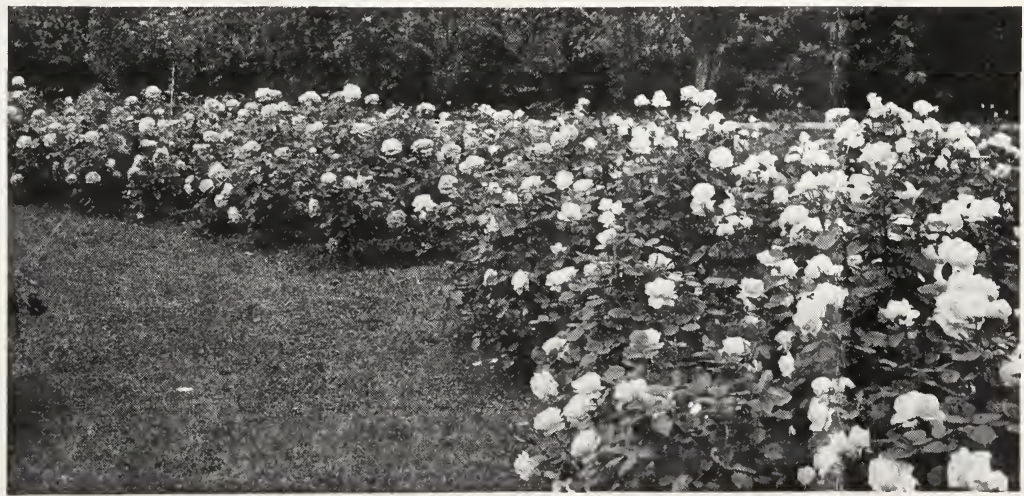



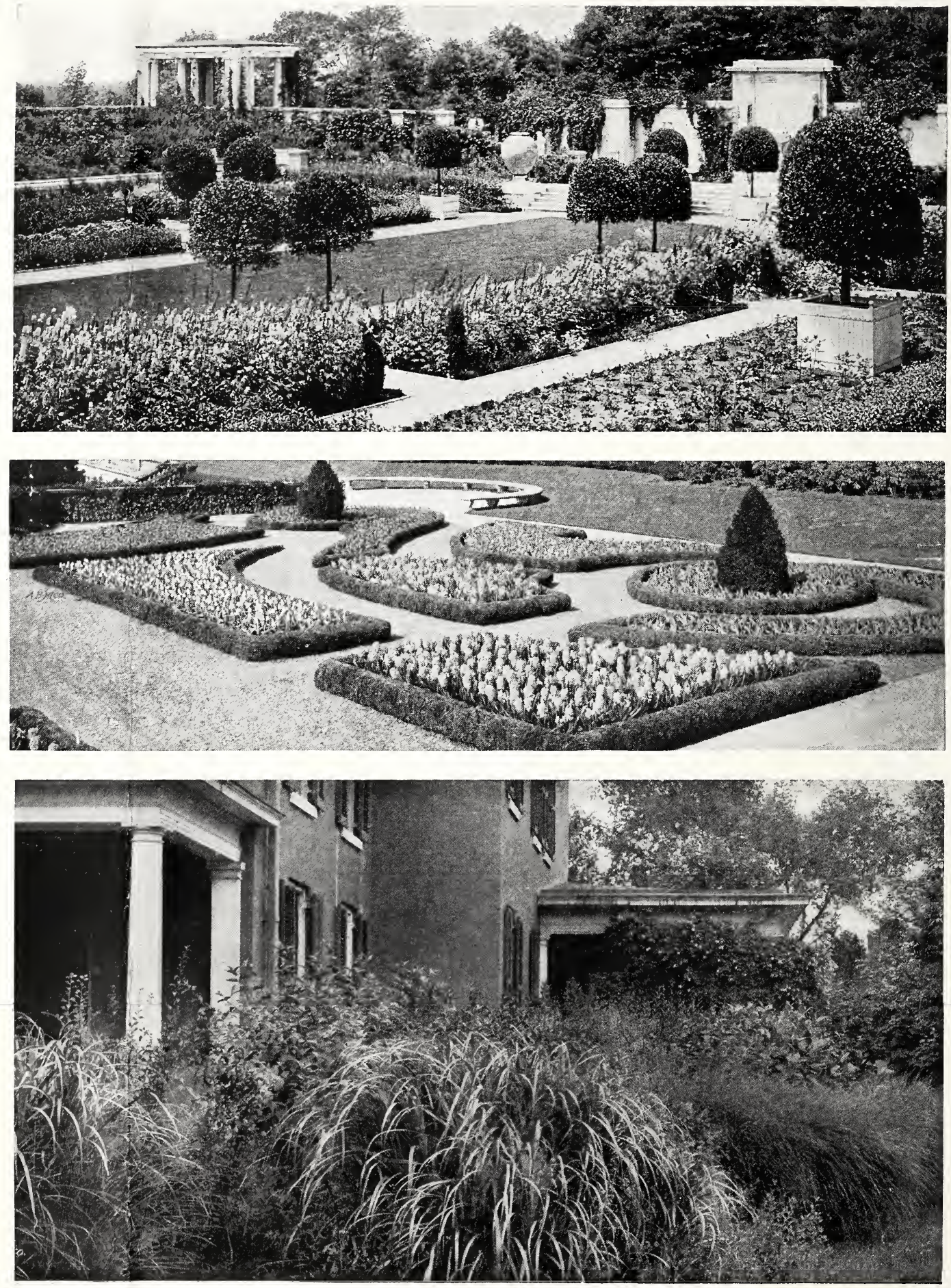


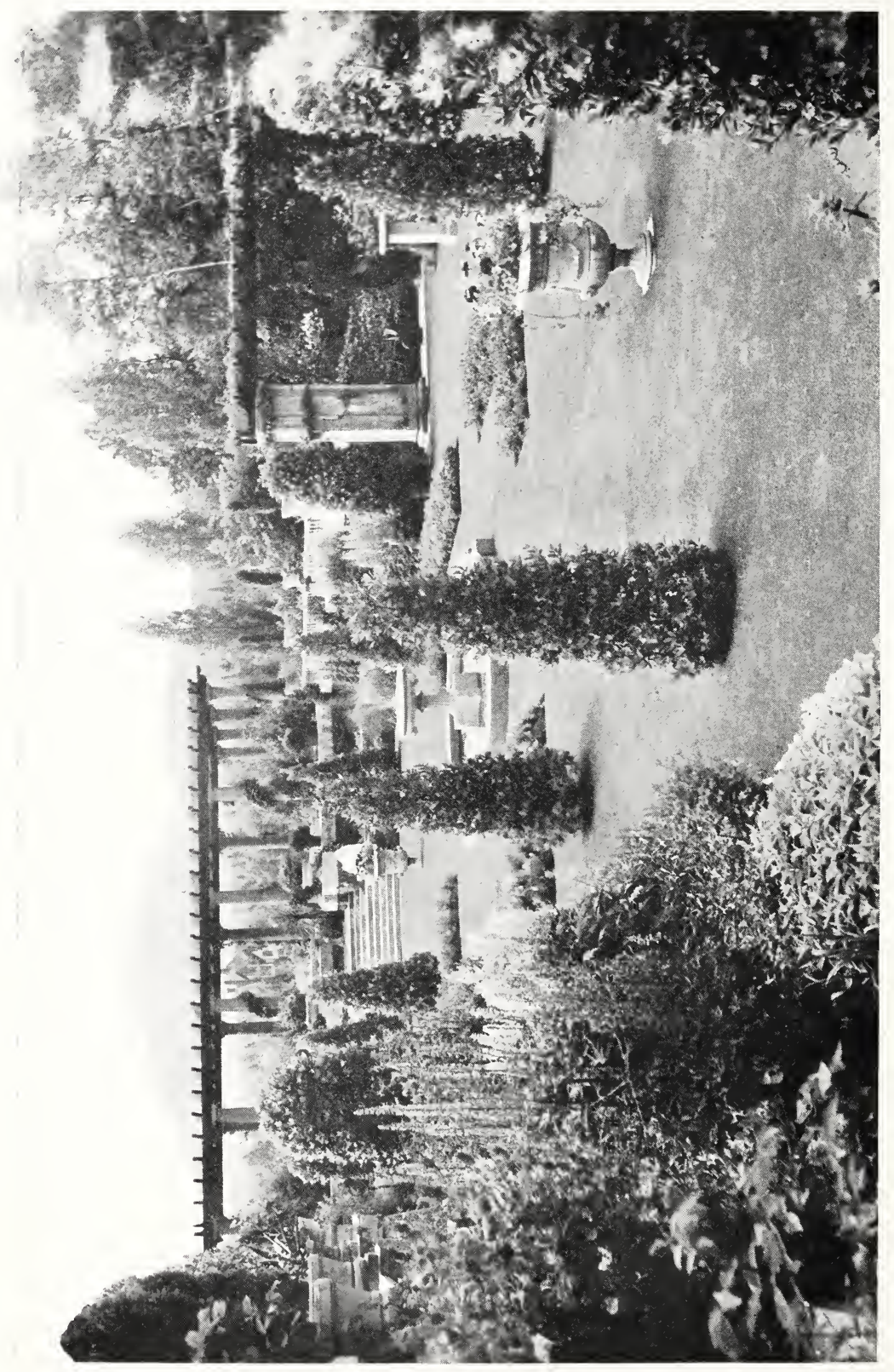

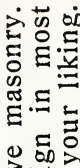
: 둥 웡 视 \& ᄃ 트 옹뭉 志品 30 들 क力口 닌 o D传 on 匹至 오묻ㄷ 으 工決 $\triangle 3$ 용 ฮึ ¿인 प⿺辶万人 近。 (1) E․ 究 I $>$ in 잉 $>$ 元 包 F 员 